\title{
Serebral palside üst ekstremite sorunları
}

\author{
Upper limb problems in cerebral palsy
}

\author{
Murat Üzel ${ }^{1}$, Bülent Güneri²
}

${ }^{1}$ Kahramanmaraş Sütçü İmam Üniversitesi Tıp Fakültesi, Ortopedi ve Travmatoloji Anabilim Dalı, El Cerrahisi Bilim Dalı, Kahramanmaraş ${ }^{2}$ Kahramanmaraş Sütçü İmam Üniversitesi Tıp Fakültesi, Ortopedi ve Travmatoloji Anabilim Dalı, Kahramanmaraş

Serebral palsili hastalarda üst ekstremite, alt ekstremiteye göre genellikle daha geri planda kalan ve daha az müdahale edilen bir konuma sahiptir. Üst ekstremite problemlerinin çözümü hastaların kendi kendine yeten bireyler olma yolunda, yaşam ve bakım kalitesinin arttırılmasında büyük önem taşımaktadır. Bu çalışmada, SP'li hastalarda sıkça rastlanan ve özellikle elin kompleks problemleri dışında kalan genel ortopedi uygulamaları içinde değerlendirilebilecek üst ekstremite problemlerinin değerlendirilmesi ve tedavi yaklaşımı konusunda güncel temel bilgilerin gözden geçirilmesi amaçlanmıştır.

Anahtar sözcükler: serebral palsi; üst ekstremite; paralitik el
In the treatment of patients with cerebral palsy, the upper limb is less prominent and intervened than the lower limb. The solution of upper limb problems is of great importance in increasing the quality of life and care, and thus making the patients self-sufficient individuals. In this study, it is aimed to evaluate the upper extremity problems which are frequently encountered in patients with cerebral palsy, and which can be evaluated in general orthopedic applications, especially excluding complex hand problems.

Key words: cerebral palsy; upper extremity; paralytic hand erebral palside (SP) hasarlanma sırasında çocuğun yaşına, beyinde tutulum bölgesine göre farklı patolojiler oluşur. Motor ve duyusal bozukluklar, koordinasyon, zekânın durumu ve nöbet varlığı prognoz belirteçleridir. Çocuğun merkezi sinir sistemindeki hasara bağlı; kas fibrozisi, atrofi, eklem kontraktürü, kemik ve eklemlerde yapısal değişiklikler, eklemlerde instabilite problemleri, ekstremite uzunluk farklıı̆̆ı, osteopeni oluşur (Şekil 1). ${ }^{[1,2]}$

Diplejik hastalarda üst ekstremitenin tutulumu alt ekstremiteye göre daha hafiftir. Özellikle hemipleji veya kuadriplejili hastalarda daha şiddetli olmak üzere, çoğu hastada üst ekstremite tutulumu görülür. Hemiplejik hastalarda, tutulan tarafta gelişme geriliği ve ekstremite uzunluk eşitsizliği ortaya çıkar. ${ }^{[3]}$

Üst ekstremitedeki spastik deformiteler; omuzda iç rotasyon, dirsekte fleksiyon, önkolda pronasyon, el bileğinde fleksiyon, parmaklarda fleksiyon, intrensek spastisite ve avuç içinde başparmak/kenetlenmiş el, parmaklarda kuğu boynu deformiteleridir. ${ }^{[4,5]}$
SP'li çocukların bakımında tüm öğeleri yönetmek için çoklu disiplinlerden oluşmuş bir ekibe intiyaç duyulur. ${ }^{[4]}$

SP'de üst ekstremite tutulumlarında tedavinin amaçları; işlevleri arttırmak, spastisite, deformite ve ağrıyı azaltmak veya ortadan kaldırmak, ekstremitenin normale yakın görünüşünü sağlamak, günlük aktivitelerde bağımsız olmasını sağlamak ve hastanın kendine olan güvenini arttırmaktır. ${ }^{[4,6]}$

SP'deki üst ekstremite cerrahisi ana nedene yönelik olmayan onarıcı ve sıklıkla önleyici bir tedavidir. [7,8] SP' li çocukların yaklaşık \%5-20'si üst ekstremite cerrahi uygulamaları için potansiyel adaydırlar. ${ }^{[5,9]}$ Üst ekstremite ameliyatlarının sadece \%50'si işlevsel düzelmeyi gerçekleştirmek için yapılmakta fakat normal ekstremite işlevine ulaşılamamaktadır. ${ }^{[10-12]}$ Ortopedik yaklaşımda, büyümekte ve gelişmekte olan bir çocukta yalnız kas iskelet sistemindeki kötüleşmenin düzeltilmeye çalışılması ile sınırlı tedavi girişimlerinin sonucu her zaman net ve kesin değildir; bu nedenle zaman içinde korunamaz hale gelebilmektedir.

- İletişim adresi: Kahramanmaraş Sütçü İmam Üniversitesi Tıp Fakültesi, Sağlık Uygulama ve Araştırma Hastanesi, Ortopedi ve Travmatoloji Anabilim Dalı, El Cerrahisi Bilim Dalı, Avşar Yerleşkesi, Oniki Şubat/Kahramanmaraş Tel: 0344 - 3003321 e-posta: drmuratuzel@gmail.com

- Geliș tarihi: 1 Ekim $2018 \quad$ Kabul tarihi: 1 Ekim 2018 


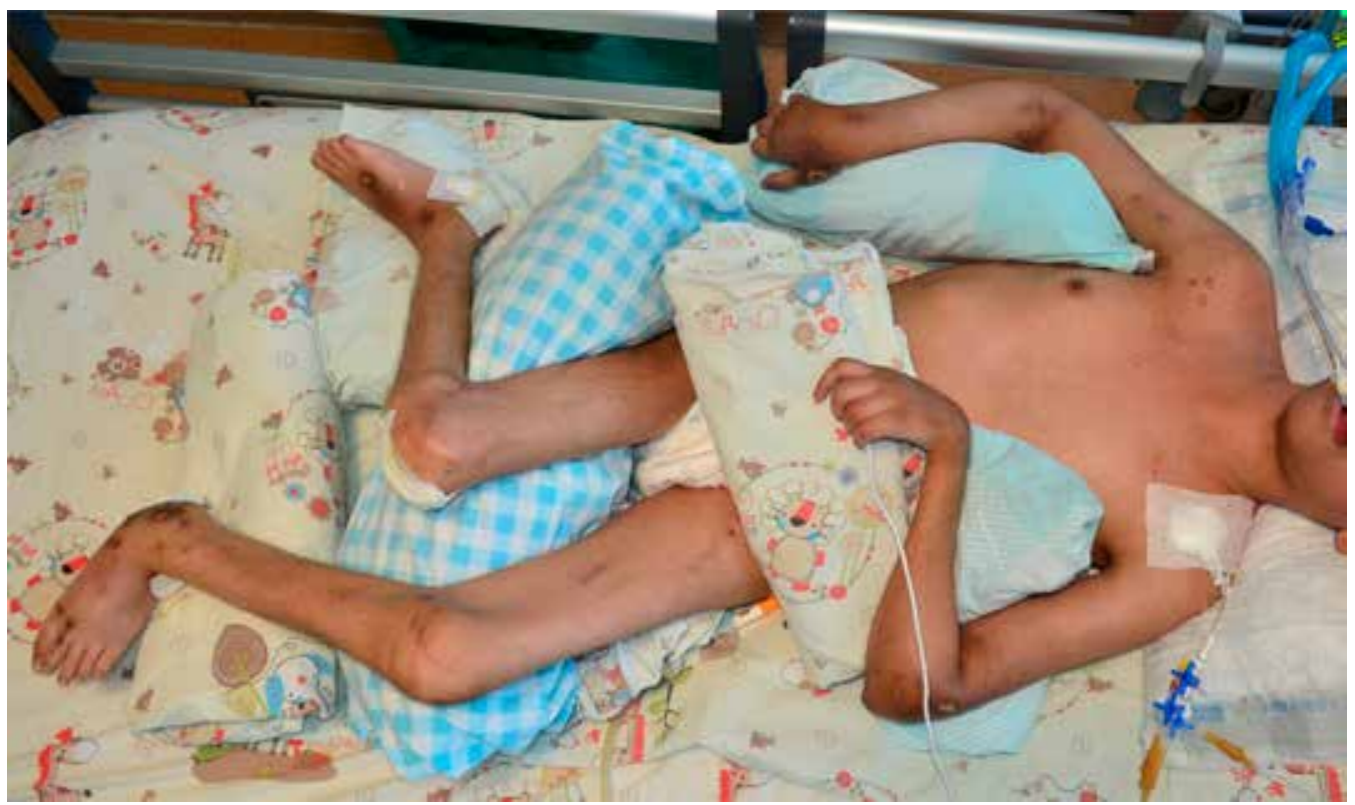

Şekil 1. Tüm beden tutulumunun olduğu spastik plejili hastada şiddetli alt ve üst ekstremite deformitelerinin görünümü. Hiçbir cerrahi tedavi yapılmamış, oral ilaç verilen ve fizik tedavi ile izlenmekte olan 17 yaşındaki hasta enfeksiyon nedeniyle yoğun bakımda tedavi görmekteydi. Deformiteleri nedeniyle pozisyon vermekte ve bakımda güçlük çekilen hastada cilte çok sayıda ülser gelişimi tespit edildi.

ilk yaklaşımda, hareket genişliğinin arttırılması, eklemlerde dengenin sağlanması ve gücün daha iyi hale getirilmesi ve/veya hasta bakımının kolaylaştırılması tasarlanmalıdır. ${ }^{[13]}$

Cerrahi tedavi tüm ekstremiteyi hedeflemeli; mümkün olabildiğince dirsek, el bileği ve parmak fleksiyon deformiteleri aynı planlamayla düzeltilmelidir. ${ }^{[4]}$

El bileği deformitesini düzeltmeksizin dirsek deformitesini düzeltmek veya parmak deformitesini düzeltmeksizin el bileği deformitesini düzeltmek, bir bütün olarak işlevi azaltabilir ve sonucu kötü hale getirebilir. Uygun hasta seçimi ve ayrıntılı değerlendirme ile gerçekleştirilmiş dikkatli kararları takiben, zamanlaması ve planlaması iyi yapılmış üst ekstremite cerrahisi sonrasında günlük yaşama katılımın ve işlevsel çalışmalarda kolun kullanılmasının daha iyi olduğu gösterilmiştir. ${ }^{[14,15]}$

\section{DEĞERLENDIRME}

ilk temel öğe doğru ve kesin tanının konulmasıdır. Her hastanın dikkatle ve baştan sona muayenesi yapılmalıdır. Hastalığı, gelişim evresi, düşünme yeteneği, motor işlevi ve duyu hissi incelenmelidir. Hasta ve yakınlarının yakınmaları, önemli ve öncelikli olarak gördükleri sorunları ve gerçekleşmesini istedikleri şeylerin sorulması gerçekçi olmayan beklentilerden kaçınmak için şarttır. Hastanın spastik ekstremitesi ile yapabildiği ve yapamadığı aktiviteler ortaya konulmalıdır. Hastalığın o kişide o anki durumunu gösteren kişisel testler, işlevsel derecelendirmeler, video analizi, elektromiyografi ve görüntüleme çalışmaları gerçekleştirilmelidir. ${ }^{[4,16]}$

SP'de, üst ekstremitedeki işlev bozukluğu genellikle bir yaş civarında fark edilir; çocuk normal gelişim ana basamaklarını gerçekleştirmede güçlük çeker. Bunlar emekleme, ayakta durmak için tutunma, nesneleri bir elden diğerine geçirme veya parmaklarla bir cisim tutmadır. Bebekler, parmak uçları ile tutmak yerine başparmakla işaret parmağının yan tarafı arasında daha ilkel anahtar tutma hareket kalıbı geliştirebilirler. Illkel reflekslerin devam etmesi, bir merkezi sinir sistemi hastalığı sürecine işaret eder. ${ }^{[17,18]}$

Hastanın hangi eli ne zaman baskın olarak kullanmaya başladığının tespit edilmesi özellikle yararlı olabilir. Bu durum genellikle üç yaşından önce ortaya çıkmaz ve daha az tercih edilen ekstremitedeki özel zayıflı̆̆ veya koordinasyon bozukluğunun işareti olabilir. ${ }^{[5]}$ Spastik hemiplejik hastalarda prematür baskın el kullanımı altı aylıkken dahi görülebilir. Normalde 12 ay civarında olan parmak ucu ile tutma gelişimi bu hastalarda gerçekleşmez. ${ }^{18,19]}$

SP'li çocuklarda duyu kapasitesinin değerlendirilmesi güçtür. Duyu bozukluklarının işlevdeki genel bozukluğa daha fazla katkıda bulunduğu kabul edilmektedir. ${ }^{[20]}$

Cerrahi müdahaleden sınırlı işlevsel yarar sağlayacakları için, istemli kontrolü az olan, belirgin distonisi olan veya sınırlı duyu hissi olan hastaları tanımlamak önemlidir. ${ }^{[4]}$ 


\section{FiZiK MUAYENE}

Spastik üst ekstremitenin fizik muayenesi zordur ve deneyim gerektir. Rahat bir ortamda ve birkaç kez tekrarlayan ziyaretlerde bir ekip yaklaşımı ile yapılacak muayenelere ihtiyaç duyulur. Sıklıkla muayene sırasında hastalarla işbirliği ve uyum güçlüğü yaşanır. Çocukların düşünme ve algılama bozuklukları değerlendirilmelidir. Hastaların her iki ekstremitesi ile aktivite yapmasını istemek onların söylenenleri anlamasını kolaylaştırır. Her bir ekstremite ayrı ayrı değerlendirilmeli ve varsa ayna hareketleri kaydedilmelidir. ${ }^{[4]}$

Muayene, hasta ve yakınlarıyla iletişim kurulması ve ekstremitelerin dinlenme pozisyonunun değerlendirilmesi ile başlar. Potansiyel sağlık problemleri için hastanın bedeni, özellikle katlanma yerleri ve cilt kıvrımları incelenmelidir. Eğer hastanın yaşı ve zekâsı uygun ise aktif hareketler yapması istenerek ekstremitelerin işlevleri değerlendirilir. Bütün ekstremitelerin pasif hareket genişliği ölçülür. Tüm tutulmuş kasların ve transfer için potansiyel verici kasların gücü değerlendirilir. Hiperrefleksi ve klonus kaydedilir. El işlevinin hareket kalıbı, kas spastisitesi, kontraktürü tanımlanır. Deformiteler ayrıntısı ile kaydedilmelidir. Spastik kas ve/veya eklem kontraktürü birbirinden ayırt edilmelidir. Hasta rahatladığında, yalnız spastisitesi olan kişilerde eklemde tam pasif hareket genişliği sağlanır. Kas ve eklem kontraktürü olan hastalarda ise pasif hareket genişliği sınırlı kalmaya devam eder. Kas ve eklem kontraktürü erişkin hastalarda sıklıkla aynı anda vardır. Eklem kontraktürü küçük çocuklarda daha az sıklıkla gözlenir. Kas spastisitesi, spastik kuwvete karşı devamlı nazik direnç ile aşılabilir. ${ }^{[4]}$ Tutulan ekstremite sayısı, motor işlev sınıfı ve kas hareket hastalıkları, duyu işlevi değerlendirilir.

Ileri değerlendirme çocukla iletişimi gerektirir; bu, genellikle dört yaşından önce mümkün değildir. İletişim kurabilen çocuklarda stereognozis test edilmelidir. Bunun için çocuğun gözü kapalı iken eline küre ve küp verilerek bunlar arasında fark olup olmadığı sorulabilir. Daha ayrıntılı muayene eline verilen sivri veya künt uçlu cisimleri, bilinen nesneleri, örneğin para, kâğıt, kumaş tanıması veya ısı farklııkları test edilerek yapılabilir. ${ }^{[5,21]}$

Stereognozisin, duyarlılığın bozulmasının en hassas ayırt edici yöntemi olduğu tespit edilmiştir. Stereognozisi bozulmuş olan çocukların ellerini ihmal etme olasıllğı yüksektir. ${ }^{[20]}$

Muayeneyi yapan kişi, hastanın avucunu yukarı veya aşağı doğru çevirerek elin pozisyonunu sorabilir. Birçoğu normal duyuya (ince iğne, dokunma, Isı) sahip olmasına rağmen, hastaların yaklaşık yarısında duyu bozulmuş, iki nokta ayrımı, stereognozis, propriyosepsiyon, barognozis azalmış durumdadır. Duyuda oluşan bu değişiklik tutulan ekstremitenin tamamen ihmal edilmesine neden olabilir. ${ }^{[5]}$
Üst ekstremitenin genel değerlendirmesinde, hastanın kendi isteği ile elini 5-10 sn içinde başının üzerine yerleştirip daha sonra karşı diz üzerinde tutabilmesi şeklinde yeterli proksimal kontrolün olup olmadığına bakılır. Bir çocuk eğer bu derece kontrolü gösteremiyor ise onun rekonstrüksiyonu haklı gösterecek yeterlilikte ekstremitesini kullanabileceğinden şüphe duyulur. ${ }^{[5]}$

SP'li çocuklarda çeşitli skalalar kullanılarak üst ekstremite el işlevi ve performans değerlendirmesi ve de cerrahi girişim sonrası sonuç ölçümü yapılabilmektedir. Kullanılacak sistemin seçiminde tedavi edilecek kişinin ihtiyacı ve düşünülen girişim göz önünde bulundurulmalıdır. ${ }^{[22]}$

Standardize edilmiş değerlendirme araçları, sınıflama sistemlerinin kullanılması önemlidir. Bu araçlar; House işlevsel sınıflandırma, uluslararası işlev ve sakatlık sınıflaması, Melbourne tek taraflı üst ekstremite değerlendirmesi, spastisite skalaları, değiştirilmiş House işlevsel sınıflandırma ve üst ekstremite derecelendirme skalası, toplam motor performans ölçümünü içerir. ${ }^{[23-31]}$

House sınıflaması ve el kullanım yetenek sınıflama sistemi SP'li çocukların günlük aktivitede nesneleri ele alırken ellerini nasıl kullandıklarını tanımlar ve çocuğun tipik iş yapabilme yeteneğini yansıtır. Çocukların rahat veya gözlemlenmedikleri ortamlarda daha farklı şeyler yapabileceği bilinmesine rağmen olağan aktiviteleri yaparken hastanın işlevsel olarak veya videoya alınarak değerlendirilmesi veya skorlama, işlevsel testlerin (Jebsen-Taylor el işlev testi, kutu ve bloklar testi, delikli tahta testi) kullanılması yardımcı olabilir. Diğer önemli değerlendirme sistemleri; modifiye Ashworth skalası, modifiye Tardieu skalası, Melbourne tek taraflı üst ekstremite işlev değerlendirme, üst ekstremite yetenek testinin kalitesi, Shriners Hastanesi üst ekstremite değerlendirmesi, yardımcı el değerlendirmesi üst ekstremite sakatlığını derecelendirilir ve tedaviye rehberlik yapabilir (Tablo 1 ve 2). [22-26,28,30,32-34]

Koman ve ark.'nın uygulamalarında, değiştirilmiş House klasifikasyonu ve Tardieu skalasının kullanılması prognozu gösteren bir değer sağlamakta ve sonuçları tahmin edebilme yeteneğini geliştirmektedir. Hastalarda bu ölçümler kullanılmadan ameliyat kararı verilmesi önerilmez. ${ }^{[13]}$

Sınıflama ve prognozu gösteren bir araç olarak üç boyutlu hareket analizinin etkinliği ise hala inceleme konusudur. ${ }^{[4]}$

\section{Bölgesel Klinik Inceleme \\ Omuz}

Spastik bir hastada omzun en sık görülen dinlenme pozisyonu iç rotasyondur. Omzun iç rotasyon ve adduksiyonda durması subskapularis ve pektoralis 
Tablo 1. House ve ark.'nın işlevsel sınıflaması

\begin{tabular}{cll}
\hline Düzey & Kategori & Tanımlama \\
\hline 0 & Kullanmaz & Kullanmaz \\
1 & Kötü pasif yardım & Sadece ağılı̆̆ı dengeleyici olarak kullanır \\
2 & Orta pasif yardım & Ele yerleştirilmiş nesneleri tutabilir \\
3 & ìyi pasif yardım & Diğer elli kullanırken onu dengeler nesneleri tutabilir \\
4 & Kötü aktif yardım & Aktif olarak nesneleri kavrayabilir ve onları zayıf̧̧a tutar \\
5 & Orta aktif kullanım & Nesneleri aktif olarak avucunda tutar ve onları iyi dengeler \\
6 & ìyi aktifyardım & Nesneleri aktif olarak kavrar ve onları manipüle eder \\
7 & Kendiliğinden kullanım, kısmi & Her iki elle aktiviteler yapabilir ve bazen elini kendiliğinden kullanır \\
8 & Kendiliğinden kullanım, tam & Elini tamamen bağımsız olarak diğer eli hesaba katmaksızın kullanır \\
\hline
\end{tabular}

Van Heest AE, House JH, Cariello C. Upper extremity surgical treatment of cerebral palsy. J Hand Surg 1999;24-A(2):323-30. Crossref

Tablo 2. El becerisi sınıflama sistemi

\begin{tabular}{cl}
\hline Düzey & Tanımlama \\
\hline 1 & Çoğu nesneleri kolayca ve başarılı şekilde eline alır \\
2 & Çoğu nesneleri biraz azalımış kalite veya gerçekleştirme hızında eline alır \\
3 & Güçlükle nesneleri eline alır; aktiviteleri hazırlamak veya değiştirmek için yardıma ihtiyaç duyar \\
4 & Uyum sağlamış pozisyonlarda kolaylıkla yönetilen nesnelerin sınırlı seçimini elle gerçekleştirir \\
5 & Nesneleri ele almaz ve basit eylemleri bile yapmada ciddi sınırlanmış yeteneği vardır \\
\hline
\end{tabular}

Arner M, Eliasson AC, Nicklasson S, Sommerstein K, Hägglund G. Hand function in cerebral palsy: report of 367 children in a population-based longitudinal health care program. J Hand Surg 2008;33-A(8):1337-47. Crossref

major kaslarının spastisitesi ve/veya kontraktüründen kaynaklanır. Buna latissimus dorsi ve teres major kasları da katkıda bulunuyor olabilir. Zamanla glenohumeral displazi, kapsüler kontraktür ve çevrede bulunan fasyanın kalınlaşması deformiteye eklenir. Daha az sıklıkla omuzda döndürücü kas grubunun kontraktürü ve/veya spastisitesine bağlı olarak şiddetli dış rotasyon ve abduksiyon kontraktürü meydana gelebilir. Hekim işlevsel olarak elin uzayda hasta tarafından konumlandırılışını bozan omuz hareketindeki kısıtlılıkları belirlemelidir. ${ }^{[4]}$

\section{Dirsek}

Hekim, hasta yürürken, koşarken, çeşitli aktiviteleri gerçekleştirirken karşı ekstremite ile birlikte ilgili ekstremitenin dinamik dirsek pozisyonunu gözlemlemelidir. ${ }^{[35]}$ Önde gelen spastik dirsek deformitesi fleksiyondur (Şekil 2). Başlangıçtaki neden, dirsek fleksörlerinin herhangi biri veya tamamının spastisitesi ve/veya kontraktürüdür (biseps, brakiyalis, brakiyoradyalis). Uzun süreli deformiteler, yumuşak dokuda ve eklemde kontraktürlere neden olabilir. Fleksiyon deformitesi şiddeti değişik olabilir. Bazı hastalarda sadece dinamik postür şeklinde, yürürken veya iş yaparken istemsiz fleksiyon gözlenebilir. Bazı hastalarda şiddetli fleksiyon, antekübital ciltte bozulma ve kıvrımlarda enfeksiyona yol açabilir. Şiddetli hiperfleksiyon deformitesi görülebilir. Şiddetli kontraktürü azaltmak, hastanın tekerlekli sandalye kullanmasına, resim tahtasına dokunmasına, iletişim teknolojisi kullanmasına, çevresindeki nesnelere ulaşmasına izin verir. Daha az şiddetli fleksiyon deformitelerinde kontraktürün serbestleştirilmesi, yürüteç veya koltuk değneğinin kullanılmasına izin verebilir. Nesnelerin bedenden uzağa iki elle manipülasyonunu kolaylaştırır ve günlük yaşam aktivitelerindeki bağımsızlığını arttırır (Tablo 3). ${ }^{[4]}$

\section{Önkol}

Önkolun pronasyon pozisyonu temelde pronator teres (PT) kasındaki spastisiteden kaynaklanır. Pozisyon başlangıçta pasif olarak düzeltilebilir. Fakat zamanla interosseöz membranın kontraktürüne veya 


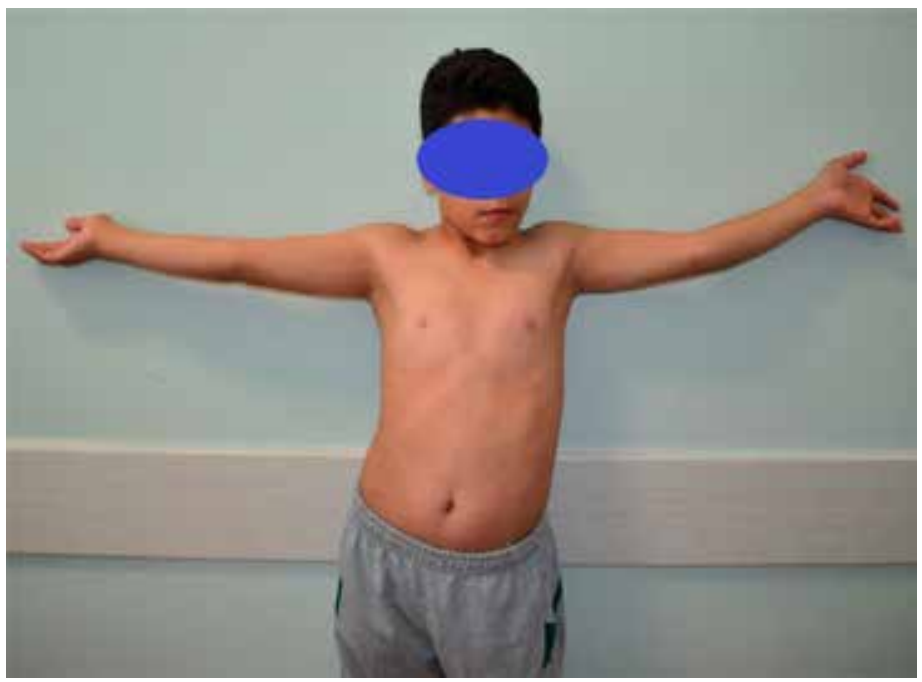

Şekil 2. Sol dirsekte hafif fleksiyon önkolda hafif pronasyon deformitesi. Spastik hemiparezili, aralıklı fizyoterapi almakta olan yedi yaşındaki hastada sol dirsekte yaklaşık $20^{\circ}$ 'lik aktif ekstansiyon kaybına yol açan dirsek fleksiyon kontraktürü ve $10^{\circ}$ 'lik aktif supinasyon kaybına yol açan pronasyon kontraktürü mevcuttu.

Tablo 3. Üst ekstremite omuz ve dirsek eklemlerinde en sık görülen deformiteler ve başlangıçta buna yol açan kaslar

\begin{tabular}{lll}
\hline & Deformite & Başlangıçtaki neden (baskın güç kaynağı) \\
\hline Omuz & İç rotasyon-adduksiyon & Subskapularis \\
& & Pektoralis major \\
& & Latissimus dorsi \\
Dirsek & Fleksiyon & Teres major \\
& & Biseps \\
& Brakiyalis \\
\hline
\end{tabular}

Hastalıktan etkilenen bölgede kas dengesizliği şekil bozukluğuna yol açar.

radyoulnar eklem(ler)in bozulmasına bağlı sabit bir deformite meydana gelebilir. Pronasyon deformitesi iki elle manipülasyonda ekstremitelerin aynı anda kullanılmasını olumsuz etkiler. Pronasyon kontraktürü ile avuç içleri birbirlerine karşılıklı yönelemez hale gelir; eller arasında küçük nesnelerin manipülasyonu daha güç olur (Şekil 3). Şiddetli spastisite ile hastalar ellerinin radyal kısmını kullanamazlar ve nesneleri kavramak için ellerinin ulnar tarafını kullanarak ters kavrama postürü varmış gibi zorlanırlar. ${ }^{[36]}$ Telafi edilemediği için, omzun iç rotasyon kontraktürü pronasyon deformitesini ağırlaştırır. Nadiren radius başı çıkığı (hastaların \%2'sinde) veya distal radyoulnar eklem çıkığı meydana gelebilir ve önkolun pasif hareket genişliğini sınırlayabilir. ${ }^{[37]}$ Spastisiteyi tanımlamak için önkolun pasif supinasyonu sırasında PT palpe edilir. Aktif supinasyon, pronasyon ve istirahat anında önkolun pozisyonu değerlendirilir. Distal ve proksimal radyoulnar eklemler çıkık, kısmi çıkık veya instabilite açısından muayene edilir. Radius başı supinasyon ve pronasyonda palpe edilir ve radius başı dizilimi belirlenir. Bir işi yapmaya çalışırken önkol rotasyonunun çalışma sahasında orta hat ve genel görev uygulaması için uygun olup olmadığı belirlenir. ${ }^{[4]}$

\section{El bileği ve parmaklar}

El bileği sıklıkla fleksiyon postüründedir. Bunlar zayıf el bileği ve parmak ekstansörleri, gergin veya spastik el bileği fleksörleri ve her ikisinin bir arada bulunmasından kaynaklanabilir. Esnek yapıdaki düzeltilebilen dinamik deformite zamanla sabit hale gelebilir. Bu durum, fleksör kasların kısalması veya kontraktürü ile ekstansör kas birimlerinin anormal uzaması, palmar kapsülün kontraktürü, el bileği ve karpal kemiklerin deformitesi veya kısmi çıkık ve/ veya kıkırdak hasarının gelişmesi ile ortaya çıkar. Ayrıca, el bileğindeki uzun süreli deformite distal radyoulnar eklemde hasara yol açarak supinasyon ve pronasyonu bloke edebilir. El bileğinin uzun süreli aşırı fleksiyondaki kötü pozisyonu median ve ulnar sinir çalışmasını bozabilir. Bu durumda, merkezi sinir sistemindeki hasar yanında periferik sinir 

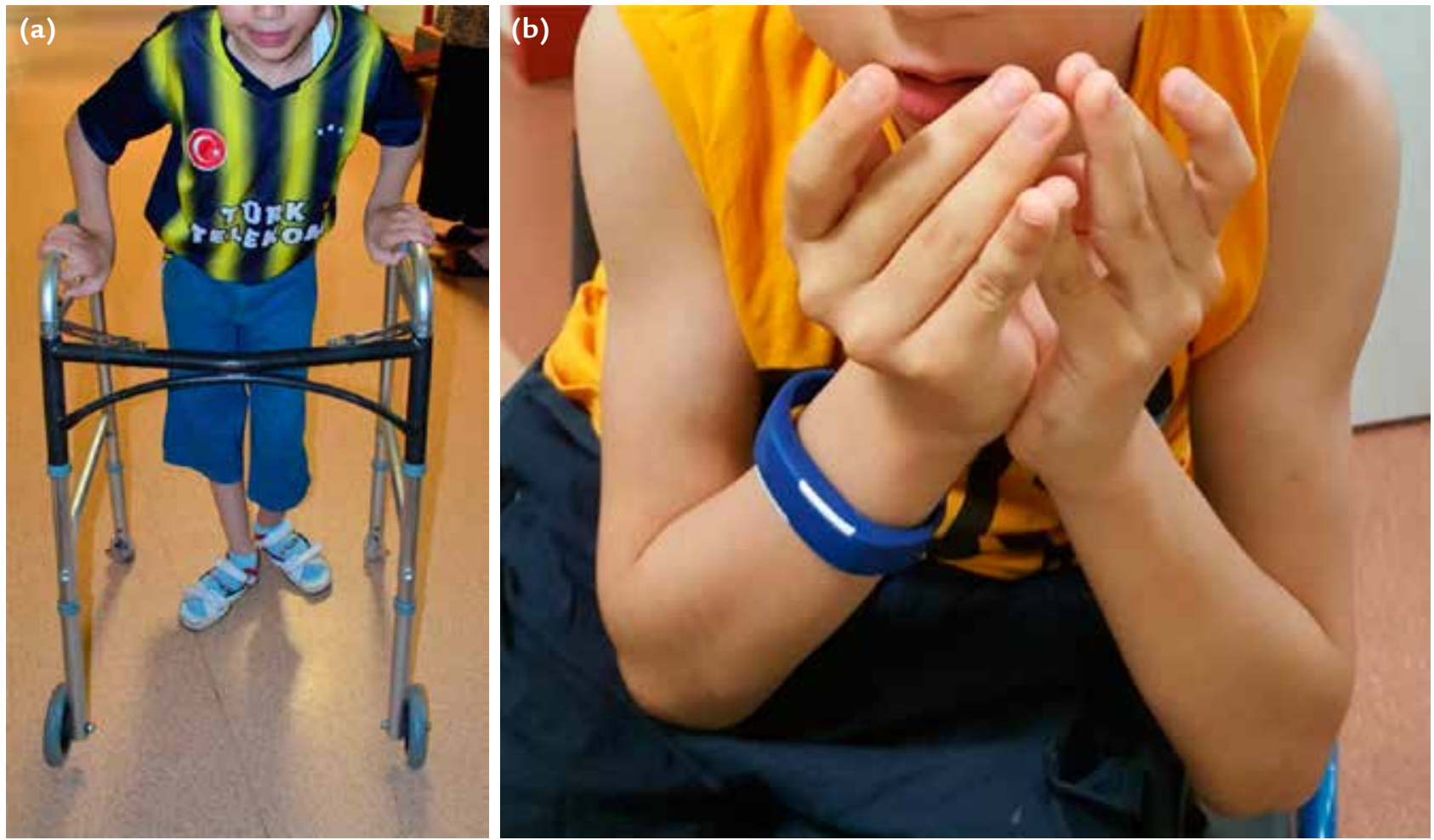

Şekil 3. a, b. Önkollarda orta derecede pronasyon kontraktürleri: Alt ekstremitede yapılan ameliyatlar sonrasında cihaz yardımıyla kendi başına yürüyebilen spastik diplejisi olan 11 yaşındaki çocukta önkollardaki pronasyon kontraktürleri cihazı tutmasını zorlaştırmaktaydı (a). Hastaya elleri ile ağzına bir şey alıyormuş gibi yapması istendiğinde el bileği eklemlerinin esnekliğini zorladığı ve güçlük çektiği görülmekteydi (b).

sistemindeki hasar da duyu değişikliği yapan bir etken haline gelebilir. ${ }^{[4,13]}$

El bileği fleksiyonu, parmak fleksörlerinin mekanik avantajını azaltır ve uzunluk-tansiyon kavsinin yer değiştirmesine bağlı olarak gücünü zayıflatır. Şiddetli kontraktürler temizlik problemlerine yol açabilir. Elin kullanımı sırasında el bileğinin pozisyonunun gözlenmesi nesnelerin alınması ve bırakılmasını değerlendirmek için çok önemlidir. Hekim, spastik kasları değerlendirebilir ve kullanım kalıbını belirleyebilir. Örneğin, el bileği fleksiyonda iken ulnar yönde sapma olmuş ise fleksör karpi ulnaris (FCU)'in spastisitesi olasıdır. EI bileğinin ekstansiyonu sırasında sirkumdiksiyon, hastanın el bileği ekstansiyonu arttırmak için ekstansör karpi ulnaris (ECU)'i kullandığını gösterir. Pasif el bileği hareketi ölçülmeli ve kaydedilmelidir. Tam olmayan pasif ekstansiyon el bileği fleksörlerinin ve hatta radyokarpal eklemin kontraktürünü anlatır. El bileği etrafındaki kaslar aktif hareket sırasında palpe edilmelidir. Spastik kaslar ve/veya aşırı ateşleme yapan kaslar değerlendirilmelidir. Örneğin, parmakların açılması sırasında fleksör karpi radyalis (FCR) veya FCU'nun ateşlenmesi spastisiteyi veya parmakların açılmasını kolaylaştırmak için aşırılaşmış yanıtı ifade eder. Volkmann açısı, kompartman sendromlu hastalarda kullanılabildiği gibi parmak fleksiyon tendonlarının gerginliğini değerlendirmek için de sıklıkla kullanılır. Parmaklar tamamen ekstansiyonda tutulurken el bileği pasif olarak maksimum ekstansiyona getirilir; yandan gözlem yapılırken fleksiyon pozisyonundaki el bileği ile önkol ekseni arasında kalan açı ölçülür. Fleksör tendon gerginliği yok ise tam el bileği ekstansiyonu ve parmak ekstansiyonu bir arada gerçekleştirilebilir. Parmak fleksiyon kontraktürü var ise parmaklar fleksiyona getirilmeden el bileğine nötral pozisyona gelecek kadar ekstansiyon yaptırılamaz. Ardından hekim, el bileğini ekstansiyonda tutarken parmakları pasif ekstansiyona getirerek fleksör dijitorum superfisyalis (FDS) veya fleksör dijitorum profundus (FDP)'un spastik olup olmadığını değerlendirebilir. Pasif olarak proksimal interfalangeal eklem ekstansiyonu kısıtlı olduğunda, FDS spastisitesinden şüphelenilmelidir (FDP spastisitesi de aynı zamanda var olabilir). Eğer proksimal interfalangeal eklemler pasif olarak tam ekstansiyona 
geliyor, fakat distal interfalangeal eklemler fleksiyon pozisyonunda kalmaya devam ediyorsa, FDP spastisitesinden şüphelenilmelidir. ${ }^{[4]}$

Bir hastanın el bileği fleksiyonda ve ekstansiyonda iken kavrama ve serbest bırakma yeteneği değerlendirilmelidir. Kötü kavrama, sıklıkla zayıf olan veya olmayan el bileği ekstansiyonuna bağlıdır. El bileği fleksiyonda iken fleksör dijitorum kasları gevşeyerek kuvvet üretimi potansiyeli en aza inecektir. El bileğini ekstansiyona getirememek zayıf olan veya olmayan el bileği ekstansörlerinden veya spastik el bileği fleksörlerinden kaynaklanabilir. Kavrama gücü el bileği ekstansör gücünü arttıracak bir tendon transferi ile daha iyi hale getirilebilir. Elde parmaklarla tutulan bir nesnenin bırakılmasının ileri derecede bozulmuş olması, zayıf olan veya olmayan parmak ekstansörlerinin sonucudur. Böyle hastalar parmaklarını aktif olarak ekstansiyona getiremezler veya sadece el bileği fleksiyonda olduğunda parmaklarını ekstansiyona getirebilirler. El bileği pasif olarak ekstansiyonda tutulduğunda aktif parmak ekstansiyonu imkânsızdır. Bu olgularda, el bileği ekstansiyonunu daha iyi hale getirmek için bir izole transfer kontrendikedir; çünkü hastalar, nesneleri yakalamak için parmaklarını ekstansiyona getirememektedirler. Tedavide, el bileği ve parmak ekstansörlerini desteklemek için bir seri tendon transferi düşünülmelidir. ${ }^{[4]}$

\section{Tanısal Testler}

\section{Görüntüleme}

SP'li hastaların tedavisinde görüntülemenin sınırlı bir rolü vardır. Direkt radyografi, uzun süreli deformitelerde kemik ve eklem değişikliklerini ortaya koymada kullanılabilir.

İşlevsel beyin manyetik rezonans (MR) görüntüleme yönteminin, üst motor nöron hastalıklarında üst ekstremite işlevini doğru olarak ortaya koymak ve aynı zamanda tedavi sonrası kortikal yeniden organizasyonu belgelemek için yararı bir ölçüm yöntemi olarak kullanılması konusunda çalışmalar yapılmaktadır. ${ }^{[38]}$

\section{Elektromiyografi}

Dinamik elektromiyografi, spastik ve flask kasların tayin edilmesi ve fazik aktivitenin belirlenmesinde yardımcı olabilir. Elektromiyografi tarafindan elde edilen bilginin ardışık fizik muayeneden alınan bilgiden daha değerli olmadığını bildirenler olmasına rağmen, cerrahide karar verme sürecinde savunulmaktadır. ${ }^{[39-42]}$

Dirsekte biseps, brakiyalis ve brakiyoradyalis (BR) spastisitesi ve olası cerrahi serbestleştirme için elektromiyografi ile değerlendirilebilir. Kavramayı oluşturacak el bileği ekstansiyonunun veya serbestleştirmeyi sağlayacak parmakların ekstansiyonunun zayıf olup olmadığı, sırayla el bileği ekstansörlerinin veya parmak ekstansör kaslarının elektromiyografik cevabı yoluyla ortaya konabilir. FCU ve parmak fleksörlerinde faz dışı veya sürekli ateşlenme sıklıkla görülür; bu özellik onları transfer için uygun olmayan kaslar haline getirir. Elektromiyografi çalışmalarında parmak veya radyal el bilek ekstansörlerinin aktivitesi sıklıkla yoktur. ECU bulguları ise daha değişkendir. ${ }^{[4]}$

Parmaklarla kavranmış bir nesnenin serbest bırakılması yani parmakların açılması sırasında ateşlenen kaslar parmak ekstansiyonunu daha iyi hale getirmek için yapılacak transferlerde tercih edilecek adaylardır. El kavramasında ateşleme gösteren kaslar el bileği ekstansiyon transferi için iyi seçimdir. ${ }^{[41,42]}$ FCU, FCR, $\mathrm{BR}, \mathrm{PT}, \mathrm{ECU}$, ekstansör karpi radyalis longus kaslarının tamamı, kavramada hangi kasların aktif olduğu, serbestleştirmede hangi kasların aktif olduğunun tayini için çalışılmalıdır. ${ }^{[42,43]}$ Bazı veriler fazik aktivitenin transferden sonra gelişebileceğini düşündürdüğü için, kastaki sürekli aktivite transfer için kesin olmamasına rağmen bir göreceli kontrendikasyondur. ${ }^{[40,44]}$

Dinamik elektromiyografi testlerini yapmak için özel eğitim almış personel gereklidir ve pek çok laboratuvar bu teknik desteği verememektedir. Üst ekstremite dinamik elektromiyografisinin genel olarak uygulanabilirliği sorgulanmaya devam etmektedir. ${ }^{[4]}$

\section{TEDAVi}

Geçmişte SP'den etkilenen çocukların üst ekstremitelerinin cerrahi rekonstrüksiyondan yarar sağlamayacağına inanılırdı. Genel olarak, çocukta bir miktar elin istemli kullanımı varsa ve onun varlığından haberdarsa, cerrahi girişim potansiyel olarak deformiteyi azaltabilir ve o ekstremitenin işlevini daha iyi hale getirebilir. Ayrıca, yardımcı bir el olarak onun rolünü önemli ölçüde değiştirebilir. Fakat bir ekstremitenin tanınması ve ekstremiteyi kullanma isteği, tedavi ile öğretilebilecek veya cerrahi ile kazandırılabilecek bir özellik değildir. Elin istemli kullanımı elin pozisyonunda bir değişiklik gerçekleştirildikten sonra kazanılabilecek işlevsel düzelmenin en iyi ön gördürücüsüdür. Mental veya gelişimsel olarak geri olmayan çocuklar görünümlerinin normalleştirilmesi ve toplumda bulunurken hissettikleri utanma hissinin azaltılması ile genel olarak daha iyi hale geleceklerdir. Görüntüdeki düzelme dramatik düzeyde olabilir. Fakat bu duruma, işlevde aynı zamanda ortaya çıkan düzelme eksikliğine bağı hayal kırıklığı sıklıkla eşlik eder. ${ }^{[4,45]}$

\section{Ameliyat Dışı Tedavi}

Koruyucu tedavi seçenekleri dikkatlice düşünülerek uygulanmalıdır. Etkili olduğunda cerrahiyi geciktirebilir, 
hatta ortadan kaldırabilir. Aksi halde ise, cerrahiye ihtiyacı olan hasta sayısında artışa yol açabilir. ${ }^{[13]}$

Atelleme, güçlendirme, nörostimülasyon ve botulinum toksini ile kemodenervasyon en etkili ameliyat dışı tedavi yöntemleridir. Bu yöntemler el bileği ve parmak motorlarının aşırı kısalmasını geciktirebilir, intrensek eklem kontraktürlerini geciktirebilir veya önleyebilir ve adaptif kemik deformitesini azaltabilir. Bu yöntemlerin hiç biri tek başına optimal sonuç sağlamamaktadır. ${ }^{[13]}$

\section{Fizik Tedavi}

Baskılayıcı alçılama ve agresif atelleme, standart tedavi girişiminin sonuçlarını daha iyi hale getirmez. Zamanlama, sıklık ve müdahale tipinin değiştirildiği tedavi protokolleri, bir kombinasyonun diğerlerinden daha yararlı olduğunu ortaya koyamamıştır. ${ }^{[46]}$

Terapist, tedavide hasta ve hasta bakıcının eğitiminde çok önemli bir rol oynayabilir. Tedavi; pasif hareket genişliği hareketleri, atellerin yapılması, uyum stratejileri ve cihazların uygulanmasını içerir. Pasif hareket genişliği hareketleri ve atelleme, esnek eklem yapılarının desteklenmesi ve sabit kontraktürlerin önlenmesi için yapılır. Ekstremiteler spastisite veya değişmiş hissetme nedeniyle ciltte hasara meyilli olduğundan, atel yapımı ustalık ister. Şiddetli spastisitede tetiklenmiş spastisite cildin hasar görmesine yol açabileceği için, atel uygulamak kontrendikedir. Spastik ekstremitenin günlük aktiviteye sokulması, özellikle hemiplejik hastalarda çözülmesi zor bir sorundur. Hemiplejik hastalar söylenen görevleri normal ekstremitenin kendiliğinden hareketiyle daha kolay ve hızlı gerçekleştirebilirler. Spastik el sıklıkla "yardımcı el"in daha iyi kullanılmasına imkân verir. Fakat, aktif kullanım ele yönelik duyu motor korteks homunkulusundaki aktiviteyi destekler ve bu yolun sürdürülmesine ihtiyaç duyulur. Çocuk hastalarda terapistler, ekstremitenin kullanımını teşvik etmek yolu olarak oyunları kullanırlar. Farklı şekillerde ve boyutlardaki nesnelerin ele alınması ve kavranması, farklı kavrama kalıplarının teşvik edilmesi için kullanılır. Kısıtlamanın uyardığı hareket tedavisi, etkilenmemiş tarafın kısıtlanması yoluyla etkilenmiş tarafın kullanımını zorlar. Kısıtlama, etkilenmemiş tarafın alçıya alınması gibi çok daha kısıtlayıcı şekilde uygulanabilir. ${ }^{[47-49]}$

Kısıtlamanın uyardığı hareket tedavisi, ses ve görüntülü bilgisayar oyunlarının oynanmasına dayalı sanal gerçeklik terapisi, nöroplastisiteye dayanan başarılı rehabilitasyon uygulamalarıdır. ${ }^{[50]}$ Terapi ile birlikte zayıf veya unutulmuş kasların elektrik stimülasyonunun ilave yararı olabilir. ${ }^{[51,52]}$
Terapist, ameliyatı takiben de çok önemli bir rol oynayabilir. Tendon uzatmaları, kas serbestleştirmeleri ve tendon transferleri için terapi protokolleri oluşturulabilir. Bunlar üç evreden oluşur: Dinlendirme, hareketlendirme ve birleştirme. İyi bir terapistle sonuç çok iyi hale gelir. ${ }^{[4]}$

\section{İlaç Yardımlı Medikal Tedavi}

Bu tedavi; ağızdan alınan ilaçlar, enjeksiyonlar veya yerleştirilebilir intratekal cihazları içerir. Kas gevşeticileri (örn; benzodiazepinler ve baklofen) ve aynı zamanda nöbet önleyici ilaçların, ekstremite işlevi ve pozisyonunun yönetiminde açık bir rolleri vardır. ${ }^{[53]}$

\section{Botulinum toksini}

Botulinum toksini spastisitenin tedavisinde yararlı ilave bir tedavidir. Botulinum toksini spastisiteyi geçici olarak azaltmak için enjekte edilebilir. ${ }^{[54-56]}$ Bu uygulama herhangi bir gerginliğin çözülmesi ve antagonistik kasların işlevinin ortaya çıkartılması için daha yoğun terapiye izin verir. Botulinum toksini aynı zamanda bir kas tendon biriminde uzatmanın etkisini tahmin etmek ve değerlendirmek için de kullanılabilir. Bu değerlendirme yararlı olmayabilecek ve/veya işlev kısıtlanması ile sonuçlanabilecek cerrahiyi önleyebilir. ${ }^{[57]}$

Botilinum toksin enjeksiyonu için ideal hasta, belirgin fleksör spastisiteli, kontraktürsüz, bir miktar istemli ekstremite kontrolünün olduğu hastadır. Fikse kontraktürlerde, istemli kontrolün olmadığı ve spastisitenin olmadığı hastalarda uygun değildir. ${ }^{[57]}$

Botulinum toksin enjeksiyonu klinikte veya ameliyathanede yapılabilir. Özellikle derin kaslarda elektrik stimülasyonu veya ultrasonografi kullanılarak, iğnenin uygun yerleştirildiğinin doğrulanması gerekebilir. Enjeksiyonu takiben protokoller endikasyonla değişir. Artan sertliğin olduğu hastalara, germeyi en üst noktaya taşımak için yaklaşık üç hafta alçı uygulanır. İşlevsel değerlendirme gerektiren hastaları gün boyu hareketsiz bırakmak gerekli değildir. ${ }^{[4]}$

\section{Cerrahi Tedavi}

Cerrahi tedavi için en uygun zamanı belirlemek zordur. Çok erken uygulandığında büyümeye bağlı olarak ortaya çıkan motor dengesizlikten olumsuz etkilenebilir ya da geciktirildiğinde kontraktür veya eklem deformiteleri gelişebilir. Geç dönem cerrahiden kaçınmanın diğer nedenleri ise öğrenilen davranış kalıpları ve işlevsel uyum sağlamada yaşanabilecek güçlüklerdir. Küçük çocukta, büyüme deformitenin tekrarlamasına zemin hazırlar. Artrodez, istenmeyen ekstremite kısalığına yol açabilir. Büyümenin hızlandığı dönemde cerrahi 
uygulamalar göreceli olarak kontrendikedir ve mümkün olduğunca iskelet olgunlaşmasına yakın dönemde yapılmalıdır. ${ }^{[13]}$

Miyotomilerin erken yaşta, tendon transferlerinin ve artrodezin ise daha ileri yaşlarda uygulanması önerilir. Önkolun pronasyon, el bileğinin fleksiyon deformitelerini düzeltecek yumuşak doku ameliyatlarının erken dönemde ve kontraktürler gelişmeden önce (4-8 yaş) yapılması gerekir. Spastik hemiplejik hastaların ameliyatları için ideal hasta yaşı 5-25 arasıdır. ${ }^{[5]}$

Cerrahi tedavinin hedefleri açıkça tanımlanmalıdır. Var olan bir işlevi kolaylaştırmak, görünümü düzeltmek, hijyeni veya hemşirelik bakımını kolaylaştırmak için pozisyonda yapılabilecek bir değişiklik, cerrahi tedavinin açık bir endikasyonudur. Cerrahi hedefler; işlevi bozan kontraktürlerin serbestleştirilmesi, kısalmış kas tendon birimlerinin uzatılması yoluyla hareket genişliğinin arttırılması; parmak, başparmak, el bileği pozisyonu ve önkol rotasyonuna yeniden denge kazandırmak için tendon transferi ve denge yumuşak doku cerrahisi ile sağlanamadığı durumlarda eklem stabili-

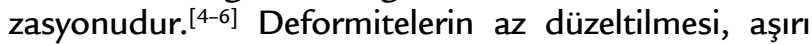
düzeltme veya işlev bozukluğuna daima tercih edilmelidir. ${ }^{[5]}$ Sonuçların nadiren devam etmesi ve kontrolü güç olmasına rağmen, spastik kaslar içerisindeki motor sinirlerin seçici nörotomisi veya kimyasal blok da spastisitenin tedavisinde bir yere sahiptir. Rizotomi spinal motor sinir köklerini ameliyatla kesip çıkartan bir cerrahi uygulamadır ve üst ekstremitede çok az uygulanmaktadır. ${ }^{[5,6]}$

Üst ekstremite cerrahisi sonrasında iyi sonucu olumlu olarak ön gördürebilen etkenler; yüksek motivasyon, uygun zekâ, duygusal stabilite, ihmal edilmemiş, iyi istemli kuvvet kontrolü ve normal duyudur. ${ }^{[4,5]}$

Cerrahi işlemin amacı hasta ve ailesi ile ayrıntılı bir şekilde tartışılmalı; olası kötü sonuçlar konusunda bilgi verilmeli ve kabul edilmiş olmalıdır. ${ }^{[6]}$

Hipertonik hareket hastalıklarından distoni ve rijiditenin varlığı, tendon transferi için göreceli bir kontrendikasyondur. Tendon transferi yapıldığında, tersi ve sabit bir eklem deformitesi ortaya çıkabilir. Bu fenomen atetoid kayma olarak adlandırımaktadır. Bu hastalarda artrodez uygulaması, sonucu en çok tahmin edilebilen bir seçenektir. ${ }^{[13]}$

\section{Ameliyat öncesi değerlendirme}

Elektif ortopedik cerrahi yapılmadan önce, diğer tıbbi durumlar en uygun şekilde kontrol altında olmalıdır. Alt ekstremiteye veya göz şekil bozukluğuna yönelik diğer cerrahi uygulamaların eş zamanlı olarak yürütülmesi uygundur. ${ }^{[6]}$

\section{Omuz}

\section{Cerrahi uygulamalar}

Terapiye ve botulinum toksinine yanıt vermeyen spastik bir omuz, gergin kasların serbestleştirilmesi veya uzatılması ile tedavi edilir. ${ }^{[58]}$ SP'de omuz etrafındaki tendon transferleri etkili değildir. ${ }^{[4]}$ Şiddetli olgularda, humeral osteotomi ekstremiteye yeni duruş şekli verebilir. ${ }^{[59]}$ Atetoid hastalarda, glenohumeral eklemin tekrarlayan çıkığı glenohumeral artrodez ile tedavi edilmelidir. ${ }^{[60]}$

Hastanın spastik kaslarının sayımı ve dökümü cerrahi tedaviye yön verecektir. Tipik olarak subskapularis ve pektoralis major kasları büyük ölçüde sorumlu kaslardır; adduksiyon ve iç rotasyon kontraktürünü azaltmak için uzatılmalıdır. Daha az yaygın olarak latissimus dorsi ve teres major kasları da serbestleştirilebilir. Dış rotasyon spastisitesi supraspinatus, infraspinatus ve teres minorun serbestleştirilmesi ile ortadan kaldırılır. Humerusta iç rotasyon osteotomisi, tekerlekli sandalyede pozisyon vermek için gerekli olabilir. ${ }^{[4]}$

Omuz internal rotasyon deformitesinde yumuşak doku serbestleştirilmesi

Endikasyonları: Cerrahi dışı tedavide başarısızık, tekrarlayan aksiller temizlik sorunları veya işlevsel elin boşlukta konumlandırılamamasıdır.

Kontrendikasyonları: İnstabiliteyi arttırabileceğinden, iç rotatorların serbestleştirilmesi omuz çıkığı veya kısmi çıkı̆̆ı olan hastalarda yapılmamalıdır. ${ }^{[9]}$ Bu hastalar omuz füzyonu için daha uygundur.

\section{Humerusun rotasyon osteotomisi}

Endikasyonları: Aşırı kontrakte omuz yumuşak doku serbestleştirilmesi ile yönetilemeyebilir. Humeral osteotomi uzayda ekstremitenin yeniden konumlanmasını sağlayabilir ve işlevini arttırabilir. Humeral osteotomi aksiller temizlik sorununu çözmez. ${ }^{[4]}$

Kontrendikasyonları: Kötü el fonksiyonu göreceli olarak humeral osteotomiye kontrendikasyon oluşturur. Elin işlevini geliştirecek cerrahi aynı anda yapılabilir. ${ }^{[4]}$

\section{Glenohumeral eklem artrodezi}

Endikasyonları: Glenohumeral eklemin ağrılı subluksasyonu veya instabilitesidir. ${ }^{[4]}$

Kontrendikasyonları: Skapular kontrolün olmaması bir kontrendikasyondur. Hastanın füzyona uğramış glenohumeral eklemi kontrol etmek için güçlü paraskapular kasları olmalıdır. ${ }^{[4]}$ 


\section{Dirsek}

Spastik, dinamik dirsek fleksiyon kontraktürünün cerrahi tedavisinde, dirseğin ön yüzünden geçen kasların miyotomisi, uzatılması, denervasyonu uygulanabilir. Kas kontraktürü serbestleştirilmesi seçenekleri biseps braki, brakiyalis ve/veya BR'in ayrı ayrı serbestleştirilmesi veya uzatılmasını içerir. İlave olarak, fleksör pronator kaslar dirsek fleksiyon kontraktürüne katkıda bulunuyor olabilir. Aynı anda fleksör pronator kaydırma uygulamasına ihtiyaç duyulabilir. Sabit uzun süreli kontraktürlere ayrıca cilt, yumuşak doku ve eklem faktörleri de eklenir. Serbestleştirmede, ciltte Z plasti ve eklem kapsül serbestleştirmesi gerekebilir. Düzeltme miktarını sınırlayan faktör sıklıkla nörovasküler yapılardır. Kapsül serbestleştirmesinden kaçınmak uygun olabilir. Dirsek ekstansiyonunda ilave kazanımlar sağlamak için cilt, fasya ve kasların cerrahi uzatma ve/veya serbestleştirmesini takip eden seri ardışık alçılama yapılabilir. ${ }^{[4]}$

\section{Muskülokutanöz nörektomi}

Endikasyonları: Nadiren yapılır. Nörektominin $30^{\circ}$ 'den az spastik deformitede etkili olduğu bildirilmiştir. ${ }^{[60,61]}$ Nörektomi biseps ve brakiyalis kaslarının sinir desteğini ortadan kaldırır ve sonuçta geride BR ile gerçekleştirilen aktif dirsek fleksiyonu kalır. Bu girişim eklem etrafındaki kontraktürleri düzeltmeyecektir. Bu nedenle eklemde tam pasif hareket genişliği mevcut olmalıdır. ${ }^{[4]}$

Kontrendikasyonları: Günlük yaşam aktiviteleri için gerekli olan pozisyonlara elini getiren işlevsel dirseği olan hastalarda kontrendikedir. Nörektomi sadece kas spastisitesine yöneliktir; sabit kontraktür varlığında kontrendikedir. Biseps veya brakiyalis için ayrı ayrı uygulanabilir. Ayrıca, muskülokutanöz nörektomi, lateral antebrakiyal kutanöz sinirin his alanı olan lateral kolda duyu yokluğuyla sonuçlanır. Sadece motor dalların nörektomisi bu duyunun korunmasını sağlar. ${ }^{[4]}$

\section{Dinamik spastisitede dirsek fleksörlerinin uzatılması}

Endikasyonları: Biseps, brakiyalis ve BR serbestleştirilmesi veya uzatılması dirseğin spastik fleksiyon kontraktürüne doğrudan yaklaşan bir yöntemdir. ${ }^{[62-64]}$ Girişim aktif dirsek ekstansiyonunu $40^{\circ}$ civarında arttırabilir; fleksiyon hareket genişliğinde veya işlevsel fleksiyon gücünde minimal kayıp görülebilir. ${ }^{[8]}$

Kontrendikasyonları: Sadece uzatma yapmak; cilt, kapsül ve eklem kontraktürlerinin varlığında kontrendikedir. Hastanın ameliyat öncesinde aktif güçlü dirsek fleksiyonu olmalıdır. Fleksörlerin uzatılması dirseği zayıflatabilir ve el ağız aktivitelerini bozabilir. Ameliyat öncesi muayenede tespit edilen spastisitenin durumuna göre, önkol supinasyonuna katkısı düşünülerek biseps uzatılabilir veya uzatılmayabilir. ${ }^{[4]}$

\section{Sabit dirsek deformitesinde kontraktür serbestleştirilmesi}

Endikasyonları: İşlevsel üst ekstremitede $40^{\circ}$ 'den daha fazla dirsek fleksiyon kontraktürü, çözülmesi gereken bir sorundur. İşlevsel özelliği olmayan üst ekstremitede tekrarlayan cilt kıvrımı enfeksiyonları ve elbise giyinme çıkarmadaki güçlüklere yol açan bir fleksiyon kontraktürü varsa endikedir. Ekstremitenin fleksiyon kontraktüründe $45^{\circ}$ 'lik düzelme genellikle elde edilmelidir. Pek çok hasta ameliyat öncesi güç olan eylemleri gerçekleştirebilir. Tekerlekli sandalyeye bağımlı olan hastalarda $100^{\circ}$ 'den daha fazla olan fleksiyon kontraktürleri, taşıma sırasında yardımı güçleştirir; nesnelerin veya masa üstündeki teknolojik cihazların ele alınmasını imkânsız hale getirir. Dirseğin serbestleştirilmesi, masa üstündeki çalışma ve transfer sırasındaki yardım yeteneğini daha iyi hale getirir. Dolaşabilen hastalar, iki eli kullanarak yaptıkları aktivitelerde kolun işlevinin ve ekstremitenin çalışılabilir uzanma mesafesinin düzelmesini isteyebilirler. ${ }^{[4]}$

Kontrendikasyonlar: Fleksiyonun zayıf olduğu hastalarda dirsekte tam serbestleştirme sonrası işlev kaybı olabilir. El bileği, parmaklar ve/veya başparmakta şiddetli sorun var ise cerrahi çözümü dirsekte planlanan girişim ile aynı anda yapılır. ${ }^{4]}$

\section{Önkol}

Önkolunda spastisitesi olan çocukta denge ve hareket açısından unutulmuş bir eklemdir. Hareket, supinasyonu sağlayan iki kas (biseps ve supinatör) ve pronasyonu sağlayan iki kas (pronator kuadratus ve pronator teres) tarafindan sağlanmaktadır. Spastik önkol klasik olarak hiperpronasyon pozisyonundadır. Önkoldaki spastik pronasyon kuvvetini azaltmak için brakiyalis ve BR transferleri gibi birkaç cerrahi uygulama tanımlanmıştır. ${ }^{[65,66]}$ PT'nin serbestleştirilmesi, fleksör pronator kaydırma yoluyla origoda veya PT'nin tenotomisi yoluyla insersiyoda veya başlama alanında gidiş yolunu değiştirme ile yapılabilir. Çalışmalarda, pronator tenotomiyle $54^{\circ}$, PT'nin yolunu sonlanma alanında değiştirme ile $46-78^{\circ}$ arasında aktif supinasyon artışı sağlandığı bildirilmektedir. ${ }^{[67-69]}$ PT'nin yolunu değiştirmek, aktif supinator olarak işlev görmesine karşın, önkola sadece yeni bir pozisyon vermektedir. Pronator kuadratus, PT serbestleştirmesi sırasında serbestleştirilmemelidir; zira bu pronasyonun kaybıyla sonuçlanabilir. Bu eylem, masa üstü çalışmaları için ve iletişim ve günlük yaşamın çok sayıda teknoloji temelli aktiviteleri için çok önemlidir. ${ }^{[70]}$

Önkol uzunca bir süre pronasyonda kalacak olursa, bu pozisyonda kontraksiyon gelişebilir. Bu sırada proksimal ve distal radyoulnar eklemde yapısal değişiklikler oluşur. Tendon transferleri, sabit kontraktür veya radius 
başı çıkı̆̆ı olduğunda kontrendikedir. ${ }^{[71]} \mathrm{Bu}$ durumda seçenekler; tendon transferinin eklendiği interosseöz membran serbestleştirmesi, radius ve/veya ulna osteotomisi veya tek kemikli önkol girişimidir. ${ }^{[72,73]}$

Cerrah, ekstremite ameliyatını bir bütün olarak planlanmalı; sonuçlarını tüm etkisini göz önünde bulundurarak değerlendirmelidir. Laboratuvarda FCU'nun ekstansör karpi radyalis brevis (ECRB)'e transferi $84^{\circ}$ 'lik supinasyon, BR'nin yolunun değiştirilmesi $33^{\circ}$ 'lik supinasyon gerçekleştirirken, PT'nin yolunun değiştirilmesi ile nötrali geçen supinasyon gerçekleştirilememektedir. ${ }^{[74]}$

\section{Fleksör pronator başlama alanında kas kaydırması}

Endikasyonları: Fleksör pronator başlama alanında kas kaydırması, PT ve aynı zamanda el bileği ve parmak fleksörlerini de serbestleştirir. Önkolun pronasyon kontraktürü serbestleştirilmesine ilaveten, fleksör pronator kitle mediyal epikondilden başladığı için dirsek fleksiyon kontraktürüne katkıda bulunuyor olabilir. ${ }^{[75,76]}$

Kontrendikasyonları: Fleksör pronator kas kaydırması ya hep ya hiç uygulamasıdır; teknik bilgi ve cerrahi deneyim gerektirir. Girişim parmak fleksörlerinin aşırı zayıflı̆̆ına ve pronasyon deformitesinin aşırı düzeltilmesine yol açabilir. ${ }^{[75]}$

\section{Pronator insersiyonun serbestleştirilmesi}

Endikasyonları: Serbestleştirme tek başına aşırı pronasyonu olan fakat istemli pronasyon kontrolü olmayan hastalarda endikedir. PT insersiyon serbestleştirmesi, PT kasının deforme edici kuvvetini ortadan kaldırır. ${ }^{68,77]}$ Aktif supinasyon olmayan hastalarda pronator serbestleştirme sonrasında supinasyonu desteklemek için tendon transferine ihtiyaç duyulabilir. ${ }^{[4]}$

Kontrendikasyonları: Pronator serbestleştirme tek başına yapıldığında, aktif supinasyon eksikliği olan hastalarda deformiteyi düzeltmeyecektir. Sabit deformiteyi düzeltmek için ilave olarak interosseöz membran serbestleştirmesi ve kemik ameliyatları gerekebilir. ${ }^{[4]}$

\section{Pronator teres gidiş yolunun değiştirilmesi ameliyatı}

Endikasyonları: Aktif pronator kontrolün olduğu fakat aktif supinasyonun olmadığı hastalarda endikedir. Pronator gidiş yolunun değiştirilmesi bu kası bir supinatör haline getirir. ${ }^{[19,67,68]}$ Klinik sonuçlar, supinasyonda \%50 artışı ve ters kavrama pozisyonunun düzeldiğini ortaya koymuştur.

Kontrendikasyonu: Aktif pronasyon kontrolü olmayan hastalarda dikkatlice uygulanmalıdır. Bu durum$\mathrm{da}$, transfer sadece bir bağlama ipi olarak iş görecektir.

Hafif önkol pronasyon kontraktürü PT serbestleştirme veya yolunun değiştirilmesi yöntemleriyle tedavi edilebilir. Aktif supinasyonu olan hastalarda pronator tenotomi tercih edilmelidir. Eğer hastanın aktif pronasyonu var fakat aktif supinasyonu yok ise, PT'nin yolunun değiştirilmesi ameliyatı uygundur. Pronator kontraktürü olan hastada ilave olarak el bileği ve parmaklarda fleksiyon deformitesi de var ise, fleksör pronator kas kaydırma ameliyatı tercih edilir. Orta veya ileri derecede pronasyon deformitesi olan hastalarda radius ve/veya ulna osteotomisi veya tek kemikli önkol uygulaması tercih edilir (Tablo 4). ${ }^{[4]}$

\section{El bileği ve parmak ekstansiyonu}

Spastisitesi olan çocuklarda el işlevini daha iyi hale getirmek için el bileği ve parmakların dengesinin yeniden oluşturulması önemlidir. Her hastaya özel en iyi girişim konusundaki karar öncelikli olarak el bileği ve parmak eklemlerinin kontraktürlerinin derecesine, el bileği ve parmak fleksörlerinin spastisitesi ve tonusuna bağlıdır. ${ }^{[9,78-81]}$ Değerlendirmede güçlük çekildiği zaman, median ve/veya ulnar sinir blokları yapılmak suretiyle geçici olarak fleksör spastisite ortadan kaldırılabilir. Böylece daha iyi değerlendirme yapılabilir. ${ }^{[5,6,36]}$

El bileğinde fleksiyon deformitesine ulnar sapma eşlik edebilir. Bu tablo, FCU ve veya ECU'nun kontrakte veya spastik olmasından kaynaklanabilir. Deformiteye neden olan kas kesilebilir, uzatılabilir veya onun antagonistini desteklemek için transfer edilebilir. ${ }^{[4]}$

Muayenenin bir parçası da, el bileği hareketleri sırasında parmak işlevlerinin değerlendirilmesidir. Eğer hasta el bileğini nötral düzleme kadar aktif olarak ekstansiyona getiremiyor ise, hekim tarafindan el bileği nötralde tutulur ve parmak ekstansiyonu yapması istenir. Hastanın avucunda bir nesne tutacak şekilde aktif kavrama ve serbestleştirmesi incelenmelidir. El bileği ekstansiyonundaki düzelmelerin parmak ekstansiyonunu azaltmadığı ve nesnelerin elde tutulmasını etkilemediğinden emin olunmalıdır. Benzer şekilde, hastalar parmak ucuyla nesneleri tutarken başparmağın abduksiyonunu arttırmak için el bileğini ulnara doğru bükerek kullanıyor olabilir. Bu durumda, eğer el bileğinin ulnara bükülmesi azaltılırsa, başparmağın abduksiyonu arttırmaya yönelik eş zamanlı girişime ihtiyaç duyulabilir. ${ }^{4]}$

Daha büyük el bileği ekstansiyonundan yarar görebilecek bir hastaya işleri daha iyi hale getirecek birçok cerrahi teknik yoluyla yardımcı olunabilir. ${ }^{[9]}$ Potansiyel vericiler $\mathrm{ECU}^{[36,62]}$, FCU[43,62,80,82,83], ${ }^{\mathrm{PT}}{ }^{[84]}$ ve $\mathrm{BR}^{\prime}$ dir. $^{[85]}$ Verici tendonlar, genellikle üçüncü metakarp üzerindeki merkezi yerleşimine bağlı olarak, ECRB'ye transfer edilir. FCU transfer edildiğinde el bileği üzerindeki ulnara yönlendirme kuvvetini supinasyon etkisini azaltmak için, interosseöz membrandan geçen bir alternatif yol tanımlanmıştır. ${ }^{[86,87]}$ 
Tablo 4. Önkol pronasyon deformitesinde klinik değerlendirme ve cerrahi tedavi seçenekleri

\begin{tabular}{|c|c|c|c|}
\hline Önkol Deformitesi & Sorumlu kas & Durum & Cerrahi tedavi \\
\hline \multirow[t]{11}{*}{ Pronasyon } & Pronator teres & Sürekli kasılıyor & Serbestleştir \\
\hline & & Pronasyon kontrolü yok & \\
\hline & & Önkolda aktif supinasyon var & \\
\hline & & $\begin{array}{l}\text { PT Supinasyonda kasılıyor } \\
\text { Aktif pronasyon (+) } \\
\text { Aktif supinasyon (-) }\end{array}$ & Yolunu değiştir \\
\hline & Pronator kuadratus & & Serbestleştirme yapma \\
\hline & & + el bileği ve parmaklarda fleksiyon konraktürü & Fleksör pronator kaydırma \\
\hline & & & Brakiyoradyalis transferi \\
\hline & & & Brakiyalis transferi \\
\hline & & Orta-ileri deformite & İnterosssöz membran serbestleştirmesi \\
\hline & & & Radius ulna rotasyon osteotomisi \\
\hline & & & Tek kemikli önkol \\
\hline
\end{tabular}

Tablo 5. Parmak ekstansiyon deformiteleri ve tedavileri

\begin{tabular}{lll}
\hline Tip & Deformite & Tedavi \\
\hline I & $\begin{array}{l}\text { Nötrale göre } 20^{\circ} \text { 'den az ekstansiyondaki el bileği ile } \\
\text { aktif parmak ekstansiyonu mümkün }\end{array}$ & $\begin{array}{l}\text { Tedavi yok veya parmak ve/veya el bileği fleksörlerinin minimal kısmi } \\
\text { uzatılması }\end{array}$ \\
II $\quad \begin{array}{l}\text { Nötrale göre } 20^{\circ} \text { 'den fazla fleksiyondaki el bileği ile } \\
\text { aktif parmak ekstansiyonu mümkün }\end{array}$ & $\begin{array}{l}\text { FCU tenotomisi ve/veya el bileği ekstansiyonunun desteklenmesine ilaveten } \\
\text { parmak fleksörlerinin kısmi uzatılması }\end{array}$ \\
III $\quad$ Aktif parmak ekstansiyonu yok & FCU'nun EDC'ye transferi ile parmak ekstansiyonunun desteklenmesi
\end{tabular}

Zancolli EA, Zancolli ER, Jr. Surgical management of the hemiplegic spastic hand in cerebral palsy. Surg Clin North Am 1981; 61:395-406.

İleri düzeyde sabit el bileği kapsülünden kaynaklanan kontraktürü olan hastalarda, proksimal sıra karpektomisi tendon transferi yapılmadan önce, el bileğinin nötrale kadar ekstansiyonuna izin vermek için bir destekleyici ek ameliyat uygun olabilir. El bileği artrodezi, hijyeni daha iyi hale getirmek için kullanılabilir. ${ }^{[88]}$ Fakat füzyon, parmak tendonları üzerindeki tenodez etkisinin kaybına bağlı olarak işlevi alt düzeye düşürebilir. ${ }^{[89]}$ Zayıf parmak ekstansiyonu zayıf el bileği ekstansiyonundan daha az görülür ve daha şiddetli sakatlığa eşlik eder. ${ }^{[36]}$ FCU'nun ekstansör dijitorum kommunis (EDC)'e transferi, el bileği ekstansiyonunu da düzeltirken parmak ekstansiyonunu daha iyi hale getirmek için önerilmektedir. ${ }^{[9,62]}$ Parmak ekstansiyonu için tendon transferlerinin yapılması, el bileği ekstansiyonda iken parmaklarını aktif olarak ekstansiyona getiremeyen hastalarda yararlıdır. ${ }^{[00]}$ Zancolli üç tip parmak ekstansiyon deformitesi tanımladı ve bunlara tedavi basamakları önerdi. ${ }^{[91]}$ El bileği ve parmakta zayıf ekstansiyonu olan hastalar tendon transferi kombinasyonundan yarar görebilirler: FCU'nun EDC'ye veya ECU'nun ya da PT'nin ECRB'ye transferi (Tablo 5).
El bileği ekstansiyon transferleri sonrası, hastaların yaklaşık \%80'inde işlevin düzeldiği gösterilmiştir. ${ }^{[33,83]}$ FCU'nun ECRB'ye transferi güzel sonuçlar göstermektedir. ${ }^{[83,92]}$

Fleksör karpi ulnarisin ekstansör karpi radyalis brevise transferi (Green'in transferi)

Endikasyonları: Dinamik el bileği deformitesi, esnek el bileği eklemi, muhtemelen zayıf olmasına rağmen intakt parmak ekstansörleri ve zayıf veya olmayan el bileği ekstansiyonuna sahip hastalarda endikedir. ${ }^{[93]}$

Kontrendikasyonu: Çalışmayan FCR göreceli bir kontrendikasyondur.

\section{Ekstansör karpi ulnarisin ekstansör karpi radyalis brevise transferi}

Endikasyonlar: El bileği ekstansiyonunun desteklenmesi gereken hastalarda tercih edilir.

Kontrendikasyon: Herhangi bir aktif el bileği ekstansiyonu olmayan veya el bileğinin radyale kayarak dinlendiği hastalarda kontrendikedir. ${ }^{[4]}$ 


\section{Fleksör karpi ulnarisin ekstansör dijitorum kommunise transferi}

Endikasyon: Aktif parmak ekstansiyonu olmayan veya zayıf olan aktif hastalarda endikedir. ${ }^{[4]}$

Kontrendikasyon: İyi parmak ekstansiyonu veya zayıf el bileği ekstansiyonu olan hastalarda kontrendikedir. FCR'de istemli hareket olmalıdır.

\section{Pronator teresin ekstansör karpi radyalis brevise transferi}

Endikasyonu: FCR'si çalışmayan hastalarda kullanılacak bir seçenektir; bu durumda FCU'nun alınması kontrendikedir. Spastik FCU'nun kısmi uzatılması PT transferi ile beraber yapılmalıdır. PT, FCU veya ECU olmadığında el bileği ekstansiyonunu desteklemek için kullanılabilecek bir seçenektir. ${ }^{[4]}$

Kontrendikasyonları: Bu girişim, PT'nin kısa çektirme özelliğinin bir sonucu olarak el bileğinin hareket genişliğini kısıtlar. Pronator spastisitesi olan hastalarda göreceli olarak kontrendikedir.

\section{Brakiyoradyalisin ekstansör karpi radyalis brevise transferi}

Endikasyonu: BR diğer motor kaslar mevcut olmadığında transfer için etkili olabilir. BR'in çektirmesini arttırmak için proksimal önkola kadar açılarak ortaya konmalıdır. ${ }^{[94]}$

İşlevsel elde, el bileği veya parmak ekstansörlerine transfer yapmak için fizik muayeneye göre karar verilir. İlk önce el bileği nötral pozisyonda tutulurken aktif parmak ekstansiyonu test edilir. Eğer tam aktif ekstansiyon mümkün ise, parmak ekstansörleri için transfere ihtiyaç yoktur. Eğer tam aktif parmak ekstansiyonu mümkün değilse ve parmaklar pasif olarak ekstansiyona geliyor ise, parmak ekstansörlerini çalıştırmak için bir transfer düşünülür. FCU'nun EDC'ye transferi bu deformitede tercih edilebilir. Bu durumda parmakları hesaba katmaksızın el bileği ekstansörlerine transfer el fonksiyonlarını bozabilir; zira hasta parmaklarını açamayabilir, nesneleri tutamayabilir. ${ }^{[4]}$

El bileği tam ekstansiyonda tutulurken parmakların pasif ekstansiyonu kısıtlı ise parmak fleksörlerinin kısmi uzatılmasına ihtiyaç duyulabilir. Ardından aktif parmak ekstansiyonu el bileği fleksiyonda iken test edilir; bu pozisyonda iyi parmak ekstansiyonu gözleniyor ise gergin parmak fleksörlerinin serbestleştirilmesi sonrasında bir transferin muhtemelen gerekli olmayacağını gösterir. El bileği fleksiyonda tutulurken sınırlı aktif parmak ekstansiyonu bir transferin parmak fleksörleri uzatılmasına ilaveten ekstansiyonu desteklemek için gerekebileceğini gösterir. Parmak fleksörleri uzatılması ile birlikte genellikle FCU'nun EDC'ye transfer edilmesi iyi bir seçenektir. ${ }^{[4]}$
Parmak ekstansiyon testinden sonra el bileği ekstansiyonu test edilmelidir. El bileği fleksiyon deformitelerini işlevsel, dinamik ve statik olmak üzere üç grup şeklinde düşünmek yararlı olabilir. El bileği işlevsel deformiteleri olan hastalar iyi aktif hareket genişliğine sahip olabilirler; fakat aktivitelerini yerine getirirken el bileği fleksiyona gider. Tedavi, spastik fleksörlerin kısmi uzatılmasını (FCU) gerektirir. El bileği ekstansiyonu için transfere ihtiyaç yoktur. ${ }^{[4]}$

El bileğinin dinamik deformitelerinde tanım olarak statik kontraktür öğesi yoktur. Hastaların bir miktar sınırı aktif ekstansiyonları olabilir veya olmayabilir; fakat el bileklerini nötrale kadar ekstansiyona getiremezler. El bileğinin ve parmakların pasif ekstansiyonu değerlendirilmelidir. El bileğinin ve parmakların tam pasif ekstansiyonu var ise, el bileği ekstansiyonunu desteklemek için bir transfer endikedir. FCU'nun ECRB'ye veya ECU'nun ECRB'ye transferi yapılabilir. FCU daha fazla kuvvet sağlayacaktır fakat el bileğini çok daha fazla ekstansiyona getirme tehlikesi taşımaktadır. Aksine, ektansör karpi ulnarisin daha az gücü vardır; fakat uygun olmayan el bileği ekstansiyonu riski de bu ölçüde azdır. ${ }^{[4]}$

Sabit veya statik el bileği fleksiyon kontraktürü genellikle büyük çocuklarda veya erişkinlerde meydana gelir. İşlevi kısıtlayan bir kontraktür tedaviyi gerektirir. Nadiren bir tendon transferi mümkündür. Bu konudaki karar ameliyat sırasında verilmelidir. El bileği fleksörlerinin uzatılması veya serbestleştirilmesi sonrasında, el bileğinin pasif ekstansiyonu değerlendirilir. Pasif ekstansiyon nötrale kadar mümkün ise, FCU'nun ECRB'ye transferi yapılabilir. El bileğinde ameliyat öncesinde aktif fleksiyon veya ekstansiyon yok ise, FCR, FCU ve palmaris longusun tenotomisini takiben el bileği artrodezi tercih edilmelidir. El bileğinin füzyon pozisyonu, parmak tenodezi ile bağlantılı olacak şekilde dikkatlice tasarlanmalıdır. Parmak ekstansiyonu zayıf olduğu için, en fazla düz veya nötral plak kullanılır. Parmak ekstansiyonunun gerçek zayıflığı, parmakların açılmasını desteklemek için füzyonun bir miktar fleksiyon pozisyonunda olmasını gerektirir (Tablo 6). ${ }^{[4,95]}$

\section{El bileği ve parmak fleksör tendon gerginliği}

El bileği ve parmak fleksör gerginliği ile aynı anda el bileği ve parmak ekstansiyon zayıflığı olabileceğini düşünerek hareket etmek, iyi sonuç elde etmek için önemlidir. El bileği fleksiyon deformitesi, birincil olarak FCU tendonunun kontraktürü veya spastisitesinden kaynaklanmaktadır. FCR ve palmaris longusun katkıları daha azdır. Parmak fleksör gerginliği aynı zamanda el bileği fleksiyon deformitesine de katkıda bulunur ve bu Volkmann açısıyla ölçülebilir. Aşırı parmak fleksör tendon gerginliğinde, parmaklar 
Tablo 6. El bileği ve parmak fleksiyon deformitelerinde başlangıçta güç dengesizliğine yol açan kaslar ve tedavide kullanılabilecek tendon transferi seçenekleri

\begin{tabular}{|c|c|c|c|c|c|}
\hline $\begin{array}{l}\text { Fleksiyon } \\
\text { deformitesi }\end{array}$ & $\begin{array}{l}\text { Sorumlu } \\
\text { kaslar }\end{array}$ & $\begin{array}{l}\text { Olası } \\
\text { verici kaslar }\end{array}$ & Hedef kas & Gidiş yolu 1 & Gidiş yolu 2 \\
\hline \multirow[t]{4}{*}{ El bileği } & \multirow[t]{2}{*}{ FCU } & FCU & \multirow{4}{*}{$\begin{array}{l}\text { ECRB } \\
\text { insersiyosu }\end{array}$} & \multirow{2}{*}{$\begin{array}{l}\text { FCU -önkol ulnar kenarı } \\
\text { Supinasyon etkisi fazla }\end{array}$} & \multirow{4}{*}{$\begin{array}{l}\text { FCU -interosseöz membrandan } \\
\text { Supinasyon etkisi az }\end{array}$} \\
\hline & & ECU & & & \\
\hline & FCR & PT & & PT -önkol radyal kenarı & \\
\hline & $\mathrm{PL}$ & $\mathrm{BR}$ & & BR -önkol radyal kenarı & \\
\hline Parmak & $\begin{array}{l}\text { FDP } \\
\text { FDS }\end{array}$ & $\mathrm{FCU}$ & $\begin{array}{l}\text { EDC } \\
\text { ekstansör retinakulum proksimalinde } \\
\text { birleşmiş tendonlar }\end{array}$ & Önkol ulnar kenarı & \\
\hline
\end{tabular}

FCU, fleksör karpi ulnaris; EDC, ekstansör dijitorum kommunis; ECU, ekstansör karpi ulnaris; ECRB, ekstansör karpi radyalis brevis; PL, palmaris longus; PT, pronator teres; BR, brakiyoradyalis; FDP, fleksör dijitorum profundus; FDS, fleksör dijitorum superfisyalis.

ekstansiyonda tutulduğunda el bileğinin ekstansiyonu mümkün değildir. Aktif veya pasif el bileği ekstansiyonu nötralden daha az olduğunda, cerrahi olarak düzeltilmesine ihtiyaç duyulan fleksör tendon gerginliğini gösterir. ${ }^{[4]}$

Fleksör tendon uzatma ile ilgili birkaç cerrahi uygulama bulunmaktadır: fleksör pronator kaydırma ${ }^{[88,96]}$, kısmi uzatma prosedürü, $Z$ uzatma prosedürü ve superfisyalisin profundusa transferi. ${ }^{[81]}$ Daha az sıklıkla kemik kısaltma (proksimal sıra karpektomi) ${ }^{[97]}$ veya kama rezeksiyon artrodezi ${ }^{[36]}$ yapılabilir. El bileği fleksör tendonlarına kısmi uzatma veya $Z$ uzatma yapılabilir. Her iki FCR ve FCU tutulmuş ise, bazen uzatılabilmesine rağmen en az bir tanesi aktif el bileği fleksiyonu yapabilmek için devamlıı̆̆ını korumalıdır. ${ }^{[4]}$

Tüm parmak fleksör tendon uzatmaları, eğer sürekli değilse, geçici olarak kas gücünü zayıflatır. Fakat bu, düzelmiş el bileği ekstansiyonu ile elde edilecek parmak ucu kavrama gücündeki artışla telafi edilir. Fleksörlerin zayıflaması, kısmi uzatma yoluyla en düşük düzeyde tutulurken superfisyalisin profundusa transferi ile en belirgin hale gelir. Superfisyalisin profundusa transferi sınırlı parmak fleksiyonu ve kavraması beklendiği için birincil olarak sağlık, temizlik ana amaç olduğu zaman kullanılır. ${ }^{[98]} Z$ plasti ile uzatmanın etkisi, bu iki uzatma tekniğinin arasına düşer.

Kemik prosedürleri iskelet olarak erişkin hastalar için uygundur. Mümkün olduğunca el bileği hareketinin devamlılığı korunmalıdır.

\section{Fleksör pronator kas kaydırması}

Endikasyonları: Fleksör başlama alanı kaydırması parmakların gerçek işlevinin beklenmediği ve önkolun pronasyonda kontrakte olduğu zaman endikedir. Illave olarak parmak ve el bileği fleksörlerinin seçici uzatması mümkün olmaz. ${ }^{[4]}$

\section{Kısmi tendon uzatması}

Endikasyonları: Kısmi fleksör tendon uzatması işlevi olan elde, el bileği pasif olarak nötralde tutulurken parmakların tam olarak düzeltilemediği, fakat el bileği fleksiyona getirildiğinde parmakların tam düz hale gelebildiği durumda endikedir. Kısmi fleksör tendon uzatması fleksör tendonları uzatmanın en uygun yoludur; tendonları aşırı uzatma ve zayıflamış parmak ucu kavraması riski en azdır. ${ }^{[4]}$

Kontrendikasyonu: El bileği fleksiyonda iken parmaklar tam olarak ekstansiyona getirilemiyorsa kısmi tendon uzatmasının yeterli uzatmayı sağlama ihtimali yoktur; $Z$ uzatması veya superfisyalisin profundusa transferi bu olgularda düşünülmelidir. ${ }^{[4]}$

\section{Tendon $Z$ uzatması}

Endikasyonları: $Z$ uzatma kısmi uzatmaya göre daha fazla tendon uzatma miktarını gerçekleştirir ve uzatma sıklıkla fleksör pollisis longus tendonunu uzatmak için uygulanır. El bileği tam fleksiyonda olduğu zaman bile başparmak tam olarak ekstansiyona getirilemiyorsa, bu tendon uzatılır. Bu durumda kısmi uzatmanın yeterli olma ihtimali yoktur. Fleksör pollisis longus için yapılan uzatmanın miktarı, istenen düzeltmenin her derecesi için $0,5 \mathrm{~mm}$ olmalıdır (örneğin; $50^{\circ}$ 'lik kontraktür için $25 \mathrm{~mm}) \cdot{ }^{[4,99]}$

Kontrendikasyonu: $Z$ uzatması ayrı ayrı parmak fleksör tendonlarının uzatılması için kullanılmaz.

\section{Superfisyalisin profundusa tendon transferi}

Endikasyonları: Superfisyalisin profundusa transferi, parmak fleksörlerinin gerçek kontraktürü var olduğunda ve el bileği tam olarak fleksiyonda iken bile 
parmaklar tam olarak ekstansiyona getirilemediğinde endikedir. ${ }^{[81]}$ Eğer fleksör pollisis longus kontrakte ise, genellikle $Z$ uzatmayla tedavi edilir.

Kontrendikasyonu: Bu uygulama gerçekten parmak ucu kavramasını zayıflamasıyla sonuçlandığı için, elin işlevsel kullanımının görüldüğü hastalarda dikkatli yapilmalıdır. ${ }^{[4]}$

El bileği tam fleksiyon pozisyonundan hiç ekstansiyona alınamazsa, el bileği fleksiyonu tendonlarına $Z$ uzatması (FCR, FCU) gereklidir. Fakat, kısmi ekstansiyon yapılabiliyor ise, kısmi uzatma genellikle yeterlidir. Eğer el bileği fleksiyonda iken parmaklar pasif ve tam olarak ekstansiyona getirilebiliyor ise, el bileği ekstansiyonda iken parmakların ekstansiyonuna da izin verecek kısmi uzatma yapılmalıdır. Kısmi uzatmada, gerginlikte ince ayarlamaya müsaade etmenin ilave yararı vardır. Ameliyat sonrası erken dönemde parmağın aktif ekstansiyonu ile hastanın uzatmayı arttırmasına izin verilir. Eğer parmaklar el bileği fleksiyonda iken tam olarak ekstansiyona getirilemiyorsa, $Z$ plasti veya superfisyalisin profundusa transferine ihtiyaç vardır. Gergin el bileği ve parmak fleksörlerinin olduğu işlevsel olmayan elde, karpal kama rezeksiyonu ve el bileği artrodezi stabil bir yapı sağlar. Pozisyonu ve temizliği daha iyi hale getirir, parmak fleksörlerini etkili bir şekilde uzatır (Tablo 7 ve 8$).{ }^{[4]}$

Tablo 7. El bileği ve parmaklardaki fleksiyon deformitelerine ekstansiyon zayıflığının eşlik ettiği hastalarda değerlendirme ve cerrahi tedavi seçenekleri*

\begin{tabular}{|c|c|c|c|c|}
\hline El bilek & Parmak & Yumuşak doku cerrahisi & $\begin{array}{l}\text { Verici } \\
\text { kas }\end{array}$ & $\begin{array}{c}\text { Hedef } \\
\text { kas }\end{array}$ \\
\hline MP: Nötral & Tam aktif ekstansiyon (+) & Tendon transferi (-) & & \\
\hline MP: Nötral & $\begin{array}{l}\text { Tam aktif ekstansiyon }(-) \\
\text { Tam pasif ekstansiyon }(+)\end{array}$ & Tendon transferi $(+)$ & FCU & EDC \\
\hline MP: Ekstansiyon & Tam pasif ekstansiyon (-) & Parmak fleksörlerine kısmi uzatma (+) & & \\
\hline $\begin{array}{l}\text { MP: 1) Ekstansiyon } \\
\text { MP: 2) Fleksiyon }\end{array}$ & $\begin{array}{l}\text { 1) Tam pasif ekstansiyon (-) } \\
\text { 2) liyi aktif ekstansiyon (+) }\end{array}$ & $\begin{array}{l}\text { Parmak fleksörlerine kısmi uzatma }(+) \\
\text { Parmak ekstansiyonu için tendon transferi (-) }\end{array}$ & & \\
\hline $\begin{array}{l}\text { MP: 1) Ekstansiyon } \\
\text { MP: 2) Fleksiyon }\end{array}$ & $\begin{array}{l}\text { 1) Tam pasif ekstansiyon (-) } \\
\text { 2) Sınırlı aktif ekstansiyon (+) }\end{array}$ & $\begin{array}{l}\text { Parmak fleksörlerine kısmi uzatma (+) } \\
\text { Parmak ekstansiyonu için tendon transferi (+) }\end{array}$ & FCU & EDC \\
\hline İşlevsel fleksiyon deformitesi & & $\begin{array}{l}\text { El bileği spastik fleksörlerine kısmi uzatma (FCU) } \\
\text { El bilek ekstansiyonu için tendon transferi (-) }\end{array}$ & & \\
\hline $\begin{array}{l}\text { Dinamik fleksiyon deformitesi } \\
\text { Nötrale kadar aktif ekstansiyon (-) } \\
\text { Tam pasif ekstansiyon (+) }\end{array}$ & Tam pasif ekstansiyon $(+)$ & El bilek ekstansiyonu için tendon transferi $(+)$ & $\begin{array}{l}\text { FCU } \\
\text { veya } \\
\text { ECU }\end{array}$ & ECRB \\
\hline $\begin{array}{l}\text { Statik fleksiyon deformitesi } \\
\text { El bileği fleksörlerine uzatma veya } \\
\text { serbestleştirme - Nötrale kadar pasif } \\
\text { ekstansiyon (+) }\end{array}$ & & Tendon transferi (nadiren) & FCU & ECRB \\
\hline $\begin{array}{l}\text { Statik fleksiyon deformitesi } \\
\text { Aktif fleksiyon (-) } \\
\text { Aktif ekstansiyon (-) }\end{array}$ & & $\begin{array}{l}\text { 1) FCU, FCR, PL tenotomisi + } \\
\text { 2) El bileği artrodezi }\end{array}$ & & \\
\hline
\end{tabular}

*Önce parmaklar sonra el bileği değerlendirilir.

MP, Muayenede tutulduğu pozisyon; FCU, fleksör karpi ulnaris; EDC, ekstansör dijitorum kommunis; ECU, ekstansör karpi ulnaris; ECRB, ekstansör karpi radyalis brevis; PL, palmaris longus.

Tablo 8. El bileği ve parmak fleksör tendon gerginliğinin değerlendirilmesi ve cerrahi tedavi seçenekleri*

\begin{tabular}{lllll}
\hline El bileği & Sorumlu kaslar & Parmaklar & Sorumlu kaslar & Cerrahi girişimler \\
\hline Fleksiyon & FCU & Fleksiyon & FDP & Fleksör pronator kaydırma \\
Aktif ve pasif olarak ekstansiyon & FCR & & FDS & Kismi uzatma prosedürü \\
nötralden az & PL & & & $\begin{array}{l}\text { Z uzatma prosedürü } \\
\text { transferi }\end{array}$ \\
& & & Proksimal sıra karpektomi \\
& & & Kama rezeksiyon artrodezi \\
\hline
\end{tabular}

*Parmak fleksörlerinin katkısı Volkmann açısı ile ölçülür.

FCU, fleksör karpi ulnaris; FCR, fleksör karpi radyalis; FDP, fleksör dijitorum profundus; FDS, fleksör dijitorum superfisyalis; PL, palmaris longus. 


\section{KAYNAKLAR}

1. Holmström L, Vollmer B, Tedroff $K$, Islam M, Persson JK, Kits A, Forssberg $\mathrm{H}$, Eliasson AC. Hand function in relation to brain lesions and corticomotor-projection pattern in children with unilateral cerebral palsy. Dev Med Child Neurol 2010;52(2):145-52. Crossref

2. Tachdjian MO, Minear WL. Sensory disturbances in the hands of children with cerebral palsy. J Bone Joint Surg Am 1958;40(1):85-90. Crossref

3. Sawyer JR, Spence DD. Cerebral palsy. In: Azar F, Canale ST, Beaty JH, editors. Campbell's Operative Orthopaedics. Elsevier; 2017. p.1250-99.

4. Kozin SH, Lightdale-Miric N. Spasticity Cerebral Palsy Traumatic Brain Injury. In: Wolfe S, Pederson W, Kozin SH, Cohen M, editors. Green's Operative Hand Surgery, 7th ed. Philadelphia: Elsevier; 2017. p.1080-106.

5. Mauck BM, Jobe MT. Cerebral Palsy of the Hand. In: Azar F, Canale ST, Beaty JH, editors. Campbell's Operative Orthopaedics. Philadelphia: Elsevier; 2017. p.3638-59.

6. Karol LA, Disorders of the Brain. In: Herring JA, editor. Tachdjian's Pediatric Orthopaedics. Philadelphia: Elsevier; 2014. p.e2-67.

7. Cooper W. Surgery of upper extremity in spastic paralysis. Q Rev Pediatr 1952;7:139-44.

8. Mital MA, Sakellarides HT. Surgery of the upper extremity in the retarded individual with spastic cerebral palsy. Orthop Clin North Am 1981;12:127-41.

9. Koman LA, Gelberman RH, Toby EB, Poehling GG. Cerebral palsy: management of the upper extremity. Clin Orthop Relat Res 1990;(253):62-74. Crossref

10. Carroll RE. The treatment of cerebral palsy in the upper extremity. Bull N Y Orthop Hosp 1958;3:3-9.

11. Carroll RE, Craig FS. The surgical treatment of cerebral palsy: I. The upper extremity. Surg Clin North Am 1951;30:385-96.

12. Lomita $C$, Ezaki M, Oishi S. Upper extremity surgery in children with cerebral palsy. J Am Acad Orthop Surg 2010;18(3):1608. Crossref

13. Koman LA, Smith BP. Surgical management of the wrist in children with cerebral palsy and traumatic brain injury. Hand 2014;9(4):471-7. Crossref

14. Carlson MG, Athwal GS, Bueno RA. Treatment of the wrist and hand in cerebral palsy. J Hand Surg Am 2006;31(3):48390. Crossref

15. Van Heest A, Bagley A, Molitor F, James MA. Tendon transfer surgery in upper-extremity cerebral palsy is more effective than botulinum toxin injections or regular, ongoing therapy. J Bone Joint Surg Am 2015;97(7):529-36. Crossref

16. Waters PM, Zurakowski D, Patterson P, Bae DS, Nimec D. Interobserver and intraobserver reliability of therapistassisted videotaped evaluations of upper-limb hemiplegia. J Hand Surg Am 2004;29(2):328-34. Crossref

17. Erhardt RP. Sequential levels in development of prehension. Am J Occup Ther 1974;28(10):592-6.

18. Erhardt RP. Sequential levels in the visual-motor development of a child with cerebral palsy. Am J Occup Ther 1987;41(1):439. Crossref

19. de Roode CP, James MA, Van Heest AE. Tendon Transfers and Releases for the Forearm, Wrist, and Hand in Spastic Hemiplegic Cerebral Palsy. Tech Hand Surg 2010;14(2):12934. Crossref

20. Van Heest AE, House J, Putnam M. Sensibility deficiencies in the hands of children with spastic hemiplegia. J Hand Surg Am 1993;18(2):278-81. Crossref
21. Kinnucan E, Van Heest A, Tomhave W. Correlation of motor function and stereognosis impairment in upper limb cerebral palsy. J Hand Surg Am 2010;35(8):1317-22. Crossref

22. Wagner LV, Davids JR. Assessment tools and classification systems used for the upper extremity in children with cerebral palsy. Clin Orthop Relat Res 2012;470(5):125771. Crossref

23. Van Heest AE, House JH, Cariello C. Upper extremity surgical treatment of cerebral palsy. J Hand Surg 1999;24-A(2):32330. Crossref

24. Arner M, Eliasson AC, Nicklasson S, Sommerstein K, Hägglund G. Hand function in cerebral palsy: report of 367 children in a population-based longitudinal health care program. J Hand Surg 2008;33-A(8):1337-47. Crossref

25. Johnson LM, Randall MJ, Reddihough DS, Oke LE, Byrt TA, Bach TM. Development of a clinical assessment of quality of movement for unilateral upper-limb function. Dev Med Child Neurol 1994;36(11):965-73. Crossref

26. Randall M, Carlin JB, Chondros P, Reddihough D. Reliability of the Melbourne assessment of unilateral upper limb function. Dev Med Child Neurol 2001;43(11):761-7. Crossref

27. Rosenbaum P, Eliasson AC, Hidecker MJC, Palisano RJ. Classification in childhood disability: focusing on function in the 21st century. J Child Neurol 2014;29(8):1036-45. Crossref

28. Bohannon RW, Smith MB. Interrater reliability of a modified Ashworth scale of muscle spasticity. Phys Ther 1987;67(2):206-7. Crossref

29. Tardieu G, Shentoub S, Delarue R. A la recherche d'une technique de mesure de la spasticité. Neurologique 1954;91(2):143-4.

30. Koman LA, Williams RM, Evans PJ, Richardson R, Naughton MJ, Passmore L, Smith BP. Quantification of upper extremity function and range of motion in children with cerebral palsy. Dev Med Child Neurol 2008;50(12):910-7. Crossref

31. Boyce WF, Gowland C, Rosenbaum PL, Lane M, Plews N, Goldsmith $\mathrm{CH}$, Russell DJ, Wright V, Potter S, Harding D. The gross motor performance measure: validity and responsiveness of a measure of quality of movement. Phys Ther 1995;75(7):603-13. Crossref

32. Gong HS, Chung CY, Park MS, Shin HI, Chung MS, Baek $\mathrm{GH}$. Functional outcomes after upper extremity surgery for cerebral palsy: comparison of high and low manual ability classifcation system levels. J Hand Surg Am 2010;35(2):27783.e3. Crossref

33. Davids JR, Peace LC, Wagner LV, Gidewall MA, Blackhurst DW, Roberson WM. Validation of the Shriners Hospital for Children upper extremity evaluation. J Bone Joint Surg Am 2006;88(2):326-33. Crossref

34. Gordon AM, Duf SV. Fingertip forces during object manipulation in children with hemiplegic cerebral palsy. I. Anticipatory scaling. Dev Med Child Neurol 1999;41(3):16675. Crossref

35. Riad J, Coleman S, Miller F. Arm posturing during walking in children with spastic hemiplegic cerebral palsy. J Pediatr Orthop 2007;27(2):137-41. Crossref

36. Manske PR, Strecker WB. Cerebral palsy, brain injury, stroke: spastic disorders of the upper extremity. In: Peimer CA, editor. Surgery of the Hand and Upper Extremity, Vol 2. New York: McGraw-Hill; 1996. pp.1517-38.

37. Abu-Sneineh AK, Gabos PG, Miller F. Radial head dislocation in children with cerebral palsy. J Pediatr Orthop 2003;23(2):155-8. Crossref 
38. Horridge KA, Johnston J, Phatak V, Guadagno A. Magnetic resonance imaging of the brain in children and young people with cerebral palsy: who reports matters? Dev Med Child Neurol 2011;53(4):375-7. Crossref

39. Mowery CA, Gelberman RH, Rhoades CE. Upper extremity tendon transfers in cerebral palsy: electromyographic and functional analysis. J Pediatr Orthop 1985;5(1):69-72. Crossref

40. Samilson RL, Morris JM. Surgical improvement of the cerebralpalsied upper limb: electromyographic studies and results of 128 operations. J Bone Joint Surg Am 1964;46(6):1203-16. Crossref

41. Van Heest AE, Ramachandran V, Stout J, Wervey R, Garcia L. Quantitative and qualitative functional evaluation of upper extremity tendon transfers in spastic hemiplegia caused by cerebral palsy. J Pediatr Orthop 2008;28(6):67983. Crossref

42. Hoffer MM. The use of pathokinesiology laboratory to select muscles for tendon transfers in the cerebral palsy hand. Clin Orthop Relat Res 1993;(288):135-8. Crossref

43. Hoffer MM, Lehman M, Mitani M. Long-term follow-up on tendon transfers to the extensors of the wrist and fingers in patients with cerebral palsy. J Hand Surg Am 1986;11(6):83640. Crossref

44. Nylander G, Carlstrom C, Adolfsson L. 4.5-year follow up after surgical correction of upper extremity deformities in spastic cerebral palsy. J Hand Surg Br 1999;24(6):719-23. Crossref

45. Law M, Russell D, Pollock N, Rosenbaum P, Walter S, King G.. A comparison of intensive neurodevelopmental therapy plus casting and a regular occupational therapy program for children with cerebral palsy. Dev Med Child Neurol 1997;39(10):664-70.

46. DeLuca PA. The musculoskeletal management of children with cerebral palsy. Pediatr Clin North Am 1996;43(5):113550. Crossref

47. Crocker MD, Mackay-Lyons M, McDonell E. Forced use of the upper extremity in cerebral palsy: a single-case design. Am J Occup Ther 1997;51(10):824-33. Crossref

48. Law M, Cadman D, Rosenbaum P, Walter S, Russell D, DeMatteo C.. Neurodevelopmental therapy and upper extremity inhibitive casting for children with cerebral palsy. Dev Med Child Neurol 2008;33(5):379-87. Crossref

49. Pierce SR, Daly K, Gallagher KG, Gershkoff AM, Schaumburg SW. Constraint-induced therapy for a child with hemiplegic cerebral palsy: a case report. Arch Phys Med Rehabil 2002;83(10):1462-3. Crossref

50. Inguaggiato E, Sgandurra G, Perazza S, Guzzetta A, Cioni $G$. Brain reorganization following intervention in children with congenital hemiplegia: a systematic review. Neural Plast 2013;2013:1-8. Crossref

51. CarmickJ. Clinical use of neuromuscular electrical stimulation for children with cerebral palsy: II. Upper extremity. Phys Ther 1993;73(8):514-27. Crossref

52. Hines AE, Crago PE, Billian C. Functional electrical stimulation for the reduction of spasticity in the hemiplegic hand. Biomed Sci Instrum 1993;29:259-66.

53. Nogen AG. Medical treatment for spasticity in children with cerebral palsy. Pediatr Neurosurg 1976;2(5):304-8. Crossref

54. Autti-Ramo I, Larsen A, Peltonen J, Taimo A, Wendt L. Botulinum toxin injection as an adjunct when planning hand surgery in children with spastic hemiplegia. Neuropediatrics 2000;31(1):4-8. Crossref
55. Koman LA, Paterson Smith B, Balkrishnan R. Spasticity associated with cerebral palsy in children: guidelines for the use of botulinum A toxin. Paediatr Drugs 2003;5(1):11-23. Crossref

56. Koman LA, Smith BP, Williams R, Richardson R, Naughton $M$, Griffin L, Evans P. Upper extremity spasticity in children with cerebral palsy: a randomized, double- blind, placebocontrolled study of the short-term outcomes of treatment with botulinum A toxin. J Hand Surg Am 2013;38(3):435-46. e1. Crossref

57. Corry IS, Cosgroce AP, Walsh EG, D McClean, Graham HK. Botulinum toxin $\mathrm{A}$ in the hemiplegic upper limb: a double blind trial. Dev Med Child Neurol 1997;39(3):185-93. Crossref

58. Landi A, Cavazza S, Caserta G, Acciaro AL, Sartini S, Gagliano MC, Manca M. The upper limb in cerebral palsy: surgical management of shoulder and elbow deformities. Hand Clin 2003;19(4):631-48. Crossref

59. Skoff $\mathrm{H}$, Woodbury DF. Management of the upper extremity in cerebral palsy. J Bone Joint Surg Am 1985;67(3):500-3. Crossref

60. Hoffer MM, Lehman M, Mitani M. Surgical indications in children with cerebral palsy. Hand Clin 1989;5(1):69-74.

61. Sindou MP, Simon F, Mertens P, Decq P. Selective peripheral neurotomy (SPN) for spasticity in childhood. Childs Nerv Syst 2007;23(9):957-70. Crossref

62. Manske PR. Cerebral palsy of the upper extremity. Hand Clin 1990;6(4):697-709.

63. Manske PR, Langewisch KR, Strecker WB, Albrecht MM. Anterior elbow release of spastic elbow flexion deformity in children with cerebral palsy.J Pediatr Orthop 2001;21(6):7727. Crossref

64. Mital MA. Lengthening of the elbow flexors in cerebral palsy. J Bone Joint Surg Am 1979;61(4):515-22. Crossref

65. Ozkan T, Bicer A, Aydin HU, Tuncer S, Aydin A, Hosbay ZY. Brachialis muscle transfer to the forearm for the treatment of deformities in spastic cerebral palsy. J Hand Surg Eur Vol 2013;38(1):14-21. Crossref

66. Ozkan T, Tuncer S, Aydin A, et al. Brachioradialis re-routing for the restoration of active supination and correction of forearm pronation deformity in cerebral palsy. J Hand Surg $\mathrm{Br}$ 2004;29(3):263-68. Crossref

67. Bunata RE. Pronator teres rerouting in children with cerebral palsy. J Hand Surg Am 2006;31(3):474.e1-11. Crossref

68. Gschwind CR. Surgical management of forearm pronation. Hand Clin 2003;19(4):649-55. Crossref

69. Strecker WB, Emanuel JP, Dailey L, Manske PR. Comparison of pronator tenotomy and pronator rerouting in children with spastic cerebral palsy. J Hand Surg Am 1988;13(4):540-3. Crossref

70. Sakellarides HT, Mital MA, Lenzi WD. Treatment of pronator contractures of the forearm in cerebral palsy by changing the insertion of the pronator radii teres. J Bone Joint Surg Am 1981;63(4):645-52. Crossref

71. Pletcher DF, Hoffer MM, Koffman DM. Non-traumatic dislocation of the radial head in cerebral palsy. J Bone Joint Surg Am 1976;58(1):104-5. Crossref

72. Ezaki M, Oishi SN. Technique of forearm osteotomy for pediatric problems. J Hand Surg Am 2012;37(11):2400-3. Crossref

73. Kozin SH, Hines B. Anatomical approach to the pronator teres. Tech Hand Up Extrem Surg 2002;6(3):152-4. Crossref 
74. Cheema TA, Firoozbakhsh K, DeCarvalho AF, Mercer D. Biomechanic comparison of 3 tendon transfers for supination of the forearm. J Hand Surg Am 2006;31(10):1640-4. Crossref

75. El-Said NS. Selective release of flexor origin with transfer of flexor carpi ulnaris in cerebral palsy. J Bone Joint Surg $\mathrm{Br}$ 2001;83-B(2):259-62. Crossref

76. White WF. Flexor muscle slide in the spastic hand: the Max Page operation. J Bone Joint Surg Br 1972;54-B(3):453-9. Crossref

77. Gschwind C, Tonkin M. Surgery for cerebral palsy: Part I. Classification and operative procedures for pronation deformity. J Hand Surg Br 1992;17(4):391-5. Crossref

78. Dahlin LB, Komoto-TuFvesson Y, Salgeback S. Surgery of the spastic hand in cerebral palsy: improvement in stereognosis and hand function after surgery. J Hand Surg Br 1998;23(3):334-9. Crossref

79. Van Heest AE. Surgical management of the wrist and finger deformity. Hand Clin 2003;19(4):657-65. Crossref

80. Gelberman RH. Cerebral palsy. In: Gelberman RH, editor. Operative Nerve Repair and Reconstruction. Philadelphia: JB Lippincott; 1991. p.1455-75.

81. Braun RM, Vise GT. Sublimis to profundus tendon transfers in the hemiplegic upper extremity. J Bone Joint Surg Am 1973;55:873.

82. Green WT, Banks HH. Flexor carpi ulnaris transplant and its use in cerebral palsy. J Bone Joint Surg Am 1962;44(7):134352. Crossref

83. Thometz JG, Tachdjian M. Long-term follow-up of the flexor carpi ulnaris transfer in spastic hemiplegic children. J Pediatr Orthop 1988;8(4):407-12. Crossref

84. Colton CL, Ransford AO, Lloyd-Roberts GC. Transposition of the tendon of the pronator teres in cerebral palsy. J Bone Joint Surg $\mathrm{Br} 1976 ; 58-\mathrm{B}(2): 220-3$. Crossref

85. McCue FC, Honner R, Chapman WC. Transfer of the brachioradialis for hands deformed by cerebral palsy. J Bone Joint Surg Am 1970;52(6):1171-80. Crossref

86. Parry RG. Surgical correction of the spastic hand. Surg Clin North Am 1976;56(3):673-84. Crossref
87. Van Heest AE, Murthy NS, Sathy MR, Wentorf FA. The supination effect of tendon transfer of the flexor carpi ulnaris to the extensor carpi radialis brevis or longus: a cadaveric study. J Hand Surg Am 1999;24(5):1091-6. Crossref

88. Tonkin M, Gschwind C. Surgery for cerebral palsy: II. Flexion deformity of the wrist and fingers. J Hand Surg $\mathrm{Br}$ 1992;17(4):396-400. Crossref

89. Samilson RL, Green WL. Long-term results of upper limb surgery in cerebral palsy. Reconstr Surg Traumatol 1972;13:43-50.

90. Goldner JL. Upper extremity reconstructive surgery in cerebral palsy or similar conditions. Instr Course Lect 1961;18:169-77.

91. Zancolli EA, Zancolli ER Jr. Surgical management of the hemiplegic spastic hand in cerebral palsy. Surg Clin North Am 1981;61(2):395-406. Crossref

92. Roth JH, O'Grady SE, Richards RS, Porte AM. Functional outcome of upper limb tendon transfers performed in children with spastic hemiplegia. J Hand Surg Br 1993;18(3):299-303. Crossref

93. Kreulen M, Smeulders MJ. Assessment of flexor carpi ulnaris function for tendon transfer surgery. J Biomech 2008;41(10):2130-5. Crossref

94. Kozin $\mathrm{SH}$, Bednar $\mathrm{M}$. In vivo determination of available brachioradialis excursion during tetraplegia reconstruction. J Hand Surg Am 2001;26(3):510-4. Crossref

95. Gong HS, Kang JY, Lee JO, Chung MS, Baek GH. Wrist arthrodesis with volar plate fxation in cerebral palsy. Tech Hand Up Extrem Surg 2010;14(2):69-72. Crossref

96. Inglis $\mathrm{AE}, \mathrm{Cooper} \mathrm{W}$. Release of the flexor-pronator origin for flexion deformities of the hand and wrist in spastic paralysis: a study of 18 cases. J Bone Joint Surg Am 1966;48(5):847-57. Crossref

97. Omer GE, Capen DA. Proximal row carpectomy with muscle transfers for spastic paralysis. J Hand Surg Am 1976;1(3):197-204. Crossref

98. Braun RM, Vise GT, Roper B. Preliminary experience with superfcialis to profundus tendon transfer in the hemiplegic upper extremity. J Bone Joint Surg Am 1974;56(3):466-72. Crossref

99. Goldner JL. Upper extremity surgical procedures for patients with cerebral palsy. Instr Course Lect 1979;28:37-66. 